Capellán-Pérez, Iñigo; Álvaro Campos-Celador; and Jon Terés-Zubiaga. "Renewable Energy Cooperatives as an Instrument towards the Energy Transition in Spain.” Energy Policy 123 (December 1, 2018): 215-29. https://doi.org/10.1016/j.enpol.2018.08.064.

\title{
Renewable Energy Cooperatives as an instrument towards the energy transition in Spain
}

Iñigo Capellán-Pérez ${ }^{1}$, Álvaro Campos-Celador², Jon Terés-Zubiaga²

${ }^{1}$ Research Group on Energy, Economy and System Dynamics. Escuela de Ingenierías Industriales, Paseo del Cauce s/n, University of Valladolid, 47011 Valladolid, Spain

${ }^{2}$ Dep. of Thermal Engineering - University of the Basque Country UPV/EHU, Spain.

Corresponding authors: inigo.capellan@uva.es, alvaro.campos@ehu.eus, jon.teres@ehu.eus

Keywords: renewable energy cooperatives; energy democracy; transition to renewable energies; Spain; community energy

Author Accepted Manuscript (AAM) from the paper published in Energy Policy:

Capellán-Pérez, Iñigo; Álvaro Campos-Celador; and Jon Terés-Zubiaga. "Renewable Energy Cooperatives as an Instrument towards the Energy Transition in Spain.” Energy Policy 123 (December 1, 2018): 215-29. https://doi.org/10.1016/j.enpol.2018.08.064.

(C) 2018. This manuscript version is made available under the CC-BY-NC-ND 4.0 license http://creativecommons.org/licenses/by-nc-nd/4.0/ 
Capellán-Pérez, Iñigo; Álvaro Campos-Celador; and Jon Terés-Zubiaga. "Renewable Energy Cooperatives as an Instrument towards the Energy Transition in Spain.” Energy Policy 123 (December 1, 2018): 215-29. https://doi.org/10.1016/j.enpol.2018.08.064.

\title{
Highlights:
}

- Renewable energies offer a key transformative potential from a social point of view.

- Few RES cooperatives exist in Spain despite thousands of them currently exist in Europe.

- Current economic-political context is found to be the main barrier for their development.

- Spanish RES cooperatives feature particular organizational and operating structures.

- A flexible and conducive legislative framework might stimulate their development.

\begin{abstract}
Renewable Energy Sources (RES) offer a key transformative potential from a social point of view due to their modularity and capacity to generate energy at local level, allowing for the development of democratic and participative bottom-up initiatives. Spanish RES cooperatives, unlike other European countries, are few in number. Here, we review their development by applying the Multi-Level Perspective approach. Spanish RES cooperatives have recently come up against a hostile regulatory and economic context, which has induced specific organizational and operating structures such as the application of innovative participation methods and investment tools. RES cooperatives regularly collaborate in sharing learning processes and experiences, having also demonstrated their capacity to spread new ideas at both social and political levels. However, despite their growth and territorial spread over the last few years, RES cooperatives still have a minor presence in the Spanish energy system. Although some internal factors may limit their potential as an active instrument towards the transition to RES in the country, the regime's resistance is found to be the main barrier. This paper concludes with some recommendations for policy makers and RES cooperatives to enhance its potential role in the forthcoming energy transition process.
\end{abstract}

List of abbreviations:

- RES: Renewable Energy Sources

- PV: Photovoltaic 
Capellán-Pérez, Iñigo; Álvaro Campos-Celador; and Jon Terés-Zubiaga. "Renewable Energy Cooperatives as an Instrument towards the Energy Transition in Spain.” Energy Policy 123 (December 1, 2018): 215-29. https://doi.org/10.1016/j.enpol.2018.08.064.

- CSP: Concentrating Solar Thermal

- USA: United States of America

- MLP: Multi-Level Perspective

- EU: European Union

- REC: Renewable Energy Certificate

- SR: Special Regime

- GCC: Gas Combined Cycle

- Px1NME: Platform for a New Energy Model

\section{Table of contents}

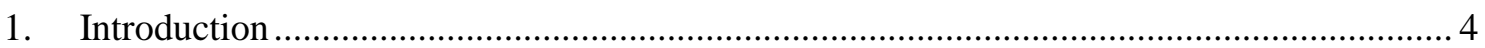

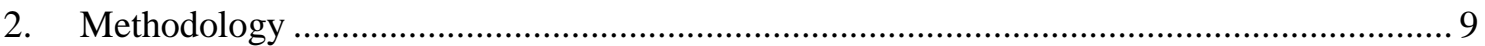

3. Development of RES cooperatives within the Spanish context ........................................ 11

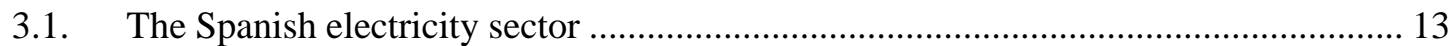

3.1.1. Regime promotion of RES in the electricity sector (1997-2012)........................ 13

3.1.2. Regime resistance to RES in the electricity sector (from 2012),.......................... 16

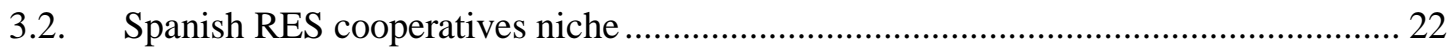

3.3. Evolution of Spanish RES cooperatives in a hostile context ...................................... 27

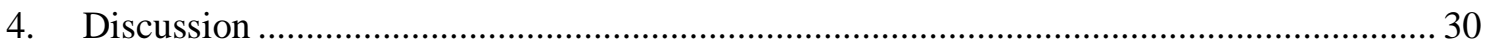

4.1 Potential of RES cooperatives as an instrument towards the energy transition in Spain .. 30

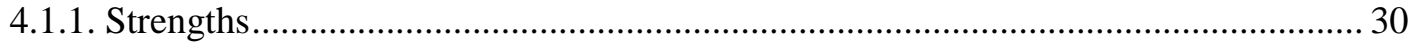

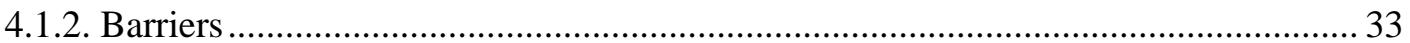

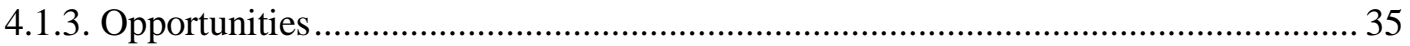

4.2. Lessons from the experience of Spanish RES cooperatives................................................ 38

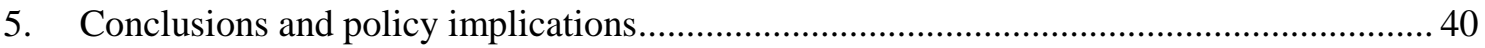

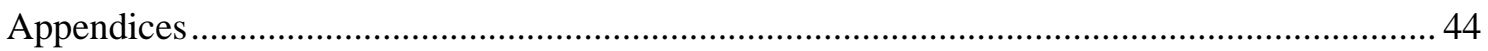

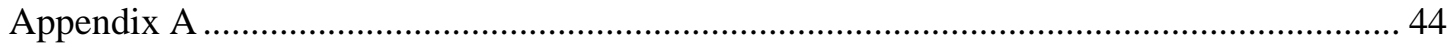

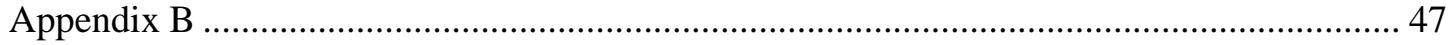

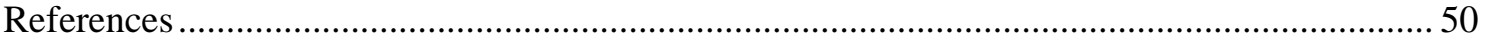


Capellán-Pérez, Iñigo; Álvaro Campos-Celador; and Jon Terés-Zubiaga. "Renewable Energy Cooperatives as an Instrument towards the Energy Transition in Spain.” Energy Policy 123 (December 1, 2018): 215-29. https://doi.org/10.1016/j.enpol.2018.08.064.

\section{Introduction}

The transition from fossil fuels to Renewable Energy Sources (RES) is an indispensable condition to achieve sustainable socio-economic systems. In particular, the interconnected challenges of climate change and fossil fuel depletion require active policies towards a fast RES transition (Capellán-Pérez et al., 2014; Wang et al., 2017). This transition is very challenging for advanced industrialized countries, where energy consumption has increased 10-15 times since the Industrial Revolution and is currently dominated by fossil fuel resources, as well as for the so-called “developing” countries, due to their lack of financial resources and expertise while facing rapid increases in energy demand (Smil, 2008).

Despite their environmental impact, fossil fuels are characterized by favorable physical-chemical properties (e.g. high power density, storable, inert at standard ambient conditions, etc.) that allow manageable, high-quality energy flows to easily supply human societies. In contrast, RES are generally characterized by lower power density levels, their use competes with other processes of the biosphere, while those with a higher potential (i.e. wind, solar) are critically affected by their intermittence and variability (de Castro et al., 2013; Hall and Klitgaard, 2012; Smil, 2015, 2015, 2008; Trainer, 2017, 2012, 2010). However, RES offer a key transformative potential from a social point of view due to their modularity and capacity to generate energy at a local level, allowing for the development of local, democratic and participative bottom-up initiatives. So, the collective ownership of RES allows the democratization of access to capital (or the means of production), and thus it has the potential to contribute to the energy transition in a socially more profound way than a mere technological fix (Barca, 2011; Huybrechts, 2013; Johanisova and Wolf, 2012; Kunze and Becker, 2015; Schneider et al., 2010). For this reason, it has the support of social movements that oppose opencast mining, fracking and fuel poverty. Additionally, the participation of local communities in the decision-making and management concerning new RES projects substantially helps to mitigate the so-called Not In My Back Yard (NIMBY) effect (Avila, 2018; Huybrechts and Mertens, 2014). Amongst RES, solar photovoltaic (PV), onshore 
Capellán-Pérez, Iñigo; Álvaro Campos-Celador; and Jon Terés-Zubiaga. "Renewable Energy Cooperatives as an Instrument towards the Energy Transition in Spain.” Energy Policy 123 (December 1, 2018): 215-29. https://doi.org/10.1016/j.enpol.2018.08.064.

wind and biomass heating are particularly attractive technologies for citizens due to their maturity, modularity, simplicity, high reliability and the availability of technical service providers, while those technologies requiring larger investments are financially unappealing to citizens (e.g. large hydro-electric power production, offshore wind power and geothermal energy) (Romero-Rubio and de Andrés Díaz, 2015).

Cooperatives and municipal utilities are the two most common collective alternatives to traditional ownership structures (Becker and Kunze, 2014; Kunze and Becker, 2014; REN21, 2016). Since Spain lacks a tradition of municipal utilities, this paper is focused on RES cooperatives ${ }^{1}$, which refer to a business model where citizens jointly own and participate in RES and energy efficiency projects. Cooperatives follow the following principles: voluntary and open membership; democratic member control; economic participation and direct ownership; autonomy and independence; education, training and information; cooperation between cooperatives and community; and environmental concern (REScoop, 2016). Hence, this model presents clear advantages to tackle the global environmental crisis in relation to the technocratic approach based on centralized ownership and electricity generation, given that the sustainability crisis is both a technic and social challenge.

Around 3,000 organizations have been reported as RES cooperatives across Europe, although with an uneven distribution (Huybrechts and Mertens, 2014; REScoop, 2016). A recent review found that "Energy Democracy” projects have spread mostly in Western Europe (Denmark, the Netherlands, Belgium, Germany, ${ }^{2}$ Austria, Northern Italy, Sweden, the UK and France), and to a

\footnotetext{
${ }^{1}$ Many terms are used in the literature for a similar concept despite different legal forms of organization: "collective and politically motivated renewable energy projects (CPEs)" (Becker and Kunze, 2014), "Sustainable energy communities (SECs)" (Romero-Rubio and de Andrés Díaz, 2015), "Renewable energy communities (RECs)" (Doci et al., 2015), "REScoops" (the European Federation of Energy Cooperatives, REScoop.eu), "Local Renewable Energy Organisations" (LREO) (Boon and Dieperink, 2014), etc. For the sake of simplicity and to avoid creating a new term, in this article, we use "Renewable Energy Sources cooperatives", i.e. "RES cooperatives" (or "RE cooperatives" in the line of (Huybrechts and Mertens, 2014)).

${ }^{2}$ (Debor, 2014) report 942 RES production cooperatives in Germany by 31 ${ }^{\text {st }}$ December 2013.
} 
Capellán-Pérez, Iñigo; Álvaro Campos-Celador; and Jon Terés-Zubiaga. "Renewable Energy Cooperatives as an Instrument towards the Energy Transition in Spain.” Energy Policy 123 (December 1, 2018): 215-29. https://doi.org/10.1016/j.enpol.2018.08.064.

lesser extent in Spain and southern Italy. These organizations are also being developed in countries where RES play only a relatively small role in the energy mix, such as France, the Netherlands or the UK. In spite of a high share of wind energy, no signs of local and democratic energy projects were found in Portugal and the Baltic countries. This is also the case for other countries where energy supply is dominated by fossil fuels, such as many of the countries in Eastern and Central Europe (Kunze and Becker, 2014). The model, with a great diversity of typologies, is present and growing in other regions of the world, such as Asia, Latin America and Africa. (ILO, 2013; REN21, 2016).

Even though there is no straightforward explanation for addressing the differences in the level of development of RES cooperatives in different countries, key factors are the historical influence of the ecologist and anti-nuclear movements, the spread of municipal utilities, the impact of the oil shock in the 1970s, together with the related policy-responses and the particular sociopolitical-cultural context (Bermejo, 2013; Huybrechts and Mertens, 2014). These organizations perform three main economic functions: the generation, distribution and retailing of renewable energy, usually under the form of electricity, although examples also exist for heating and transport.

Many cooperatives dealing with RES generation can be found across Europe. In general, European RES cooperatives started in the 1970s and 1980s with the promotion of communityowned wind energy projects but, as time went by, new RES were incorporated into their activity, such as PV production or even meeting heating needs by the use of biomass boilers o solar thermal panels connected to District Heating networks (Agterbosch et al., 2004; Boon and Dieperink, 2014; DEA, 2017; Enzensberger et al., 2003; Gotchev, 2015; Kunze and Becker, 2014; Madlener, 2007; Schreuer and Weismeier-Sammer, 2010; Vansintjan, 2015).

The specific ownership structure of the electric system in each country determines the opportunity of RES cooperatives to distribute renewable electricity. Thus, RES cooperatives are more likely to distribute electricity in those places where the electric network is publicly owned and privately 
Capellán-Pérez, Iñigo; Álvaro Campos-Celador; and Jon Terés-Zubiaga. "Renewable Energy Cooperatives as an Instrument towards the Energy Transition in Spain.” Energy Policy 123 (December 1, 2018): 215-29. https://doi.org/10.1016/j.enpol.2018.08.064.

operated after a public tender. This is the case of Germany, where citizen owned cooperatives have recently acquired the management of 90 local distribution networks around the country, alongside a wave of re-municipalization of energy networks and supply (Julian, 2014; Wagner et al., 2015). In the case of the USA, over 800 rural electric cooperatives distribute electricity to around 42 million people. Despite they use a limited share of RES generation, their contribution is rapidly increasing (Bermejo, 2013; NRECA, 2016).

RES cooperatives can also retail energy, which consists of buying energy on the market and selling it to domestic consumers (often members). However, in some cases, such as the electricity sector, the fact that most markets have only recently opened up to competition and are still de facto controlled by a small number of electrical companies makes the operation of RES cooperatives more difficult (Huybrechts, 2013).

Amongst the most significant RES cooperatives at the European level, the following can be found: Enercoop (France), comprising 10 second-order regional cooperatives (42,000 members) and 131 producers (81 MW), which delivers 245 GWh of renewable electricity to its 52,000 customers (40\% of self-sufficiency); Ecopower (Belgium), with over 50,000 members and owning a diversity of RES power plants; Energy4All (UK) which comprises 15 projects with over 10,000 members and a total equity raised of $£ 30$ million; Middelgrunden (Denmark), the first offshore wind cooperative in the country, where in 1997, about 8,600 local citizens jointly invested in a 10.2 MW offshore wind farm facing Copenhagen (REScoop, 2016); EWS (Germany) was the first civil-society initiative to take over the grid and electricity supply to a local community in the country (Schönau), and currently supplies electricity and biogas to over 160,000 members across the country and subsidizes approximately 2,600 sustainable generation units (EWS, 2016). Som Energia (Spain) can be ranked amongst the largest RES cooperatives in Europe with over 40,000 members and over 60,000 customers around the country, owning several plants of RES electricity generation that produce over 5 GWh annually (Kunze and Becker, 2014; Som Energia, 2016). 
Capellán-Pérez, Iñigo; Álvaro Campos-Celador; and Jon Terés-Zubiaga. "Renewable Energy Cooperatives as an Instrument towards the Energy Transition in Spain.” Energy Policy 123 (December 1, 2018): 215-29. https://doi.org/10.1016/j.enpol.2018.08.064.

In Spain, unlike in other countries of Europe and despite the rapid success of Som Energia, the modern RES cooperative movement is at an early stage of development. As a result, the academic literature analyzing this phenomenon in the country is scarce to date (Riutort Isern, 2015; RomeroRubio and de Andrés Díaz, 2015). In this paper, the historical development of energy cooperatives in the country from the $19^{\text {th }}$ century to the recent wave focusing on RES is reviewed, with the aim of assessing their potential as an effective instrument towards a democratic, sustainable and decentralized RES transition in Spain. Since Spanish RES cooperatives focus mainly on electricity, the recent developments in the Spanish electricity sector is also reviewed. To do so, the Multi-Level Perspective (MLP) is applied, which is a framework for analyzing socio-technical transitions, taking into account the role and capacity of the actors in the regimes as they dynamically react to potential changes threatening the status quo (Geels, 2014, 2010, 2002; Smith et al., 2005). Hence, the confrontation between the RES cooperatives emerging movement and the Spanish socio-political context is analyzed. Spain can be regarded as an interesting case study since, unlike other European countries, modern RES cooperatives have recently arisen in a hostile regulatory and economic context, creating particular organizational and operating structures to deal with the regime’s resistance (Haas, 2014; Riutort Isern, 2015). Moreover, Spain benefits from a large RES potential in comparison to other EU countries, especially for solar, due to its southern location.

The remainder of the paper is structured as follows: Section 2 describes the applied methodology, including the MLP approach. Section 3 reviews the development of RES cooperatives in Spain. Section 4 discusses, on the one hand (4.1), the strengths, barriers and opportunities of Spanish RES cooperatives as a means towards the transition to RES in Spain, and on the other, the lessons to be extracted which could be applicable to other countries (4.2). Finally, Section 5 concludes. 
Capellán-Pérez, Iñigo; Álvaro Campos-Celador; and Jon Terés-Zubiaga. "Renewable Energy Cooperatives as an Instrument towards the Energy Transition in Spain.” Energy Policy 123 (December 1, 2018): 215-29. https://doi.org/10.1016/j.enpol.2018.08.064.

\section{Methodology}

The methodology applied to perform the analysis consisted of two stages. First, the review of both academic publications and grey literature ${ }^{3}$, as well as information stemming from the direct participation and membership of the three authors in two RES cooperatives (Som Energia and EnergÉtica), allowed us to compile the relevant information about the emerging RES cooperative movement in Spain. A preliminary version of the manuscript was reviewed by seven researchers and members of different RES cooperatives around the country to ensure the consistency of the analysis.

Secondly, the Multi-Level Perspective (MLP) was applied to assess the potential of RES cooperatives as an effective instrument towards a RES transition in Spain based on democratic, sustainable and decentralized production. MLP is a methodology to analyze the dynamics between the different agents taking part in any transition process, which could be defined as large scale transformations of a societal subsystem. Even though the MLP approach was initially proposed for the assessment of technological transitions, it has also been applied to such sociotechnical transitions as the so-called "green”, "sustainable” or "low-carbon transitions” (Doci et al., 2015; Geels, 2014, 2010, 2002; Smith et al., 2005). The MLP approach identifies three sociotechnical levels through which transitions occur: landscape, regime and niche level. The three levels form a nested hierarchy; whose co-evolution is necessary in order to achieve a transition (see Table 1).

Table 1: Description of the three levels considered by the MLP methodology.

\begin{tabular}{|l|l|}
\hline Level & Description \\
\hline Landscape & $\begin{array}{l}\text { Includes the external factors that shape the regime and are beyond its } \\
\text { influence (i.e. exogenous), such as societal values, dominant political }\end{array}$ \\
\hline
\end{tabular}

\footnotetext{
${ }^{3}$ Grey literature are materials and research produced by organizations outside of the traditional commercial or academic publishing and distribution channels.
} 
Capellán-Pérez, Iñigo; Álvaro Campos-Celador; and Jon Terés-Zubiaga. "Renewable Energy Cooperatives as an Instrument towards the Energy Transition in Spain.” Energy Policy 123 (December 1, 2018): 215-29. https://doi.org/10.1016/j.enpol.2018.08.064.

\begin{tabular}{|l|l|}
\hline Level & $\begin{array}{l}\text { Description } \\
\text { ideologies, macro-economic and demographic patterns, climate change, } \\
\text { energy resources availability, etc. Changes at the landscape level put } \\
\text { pressure on the regime and can reinforce or destabilize it, eventually } \\
\text { creating windows of opportunity for transitions. }\end{array}$ \\
\hline Regime & $\begin{array}{l}\text { Represents the social, political, economic and technological framework } \\
\text { where human activities are developed. It is represented by several } \\
\text { interconnected sub-regimes (i.e., cultural, political, technological) whose } \\
\text { links tend to reinforce the existing regime and stabilize it. }\end{array}$ \\
\hline Niche & $\begin{array}{l}\text { Emerges and operates within the regime and can be defined as protected } \\
\text { spaces for innovation. These innovations have the potential for promoting } \\
\text { transitions, i.e., becoming dominant in the regime. Success depends on } \\
\text { such external factors as changes in the landscape that may result in new } \\
\text { opportunities, but also on the interactions between the niche and the } \\
\text { regime and the niche's capabilities to outpace the classical agents of the } \\
\text { regime. Witkamp et al., (Witkamp et al., 2011) distinguish market niches, } \\
\text { technological niches and social niches. }\end{array}$ \\
\hline
\end{tabular}

Many studies analyzing transition processes have focused on the potential of niches, considering the regime as a homogeneous and steady actor, hence undervaluing the role and capacity of the regime’s actors to dynamically react to potential changes threatening the status quo. For example, a close alliance between major energy companies and policy makers can be anticipated in the context to the transition to RES owing to the existing mutual interdependencies. (Geels, 2014) analyzed regime resistance, identifying four main dimensions: instrumental, discursive, material and institutional ${ }^{4}$.

\footnotetext{
${ }^{4}$ According to Geels (ibid.) instrumental resistance refers to regime actors using resources to enable their position to prevail (e.g. authority, regulation, money, personnel, capabilities, etc); discursive resistance
} 
Capellán-Pérez, Iñigo; Álvaro Campos-Celador; and Jon Terés-Zubiaga. "Renewable Energy Cooperatives as an Instrument towards the Energy Transition in Spain.” Energy Policy 123 (December 1, 2018): 215-29. https://doi.org/10.1016/j.enpol.2018.08.064.

Grassroots initiatives such as RES cooperatives are potential niches in which both technological and social innovations can emerge. In this paper, we follow the approach from Doci et al., (2015), who defined RES cooperatives as a social niche, where the technology (RES) is a mere tool for meeting social goals. Even though the alternative presented by that niche confronts the regime on a global level, in each country, this confrontation presents specific characteristics depending on the local context. In this work, the MLP is applied to explore the potential of RES cooperatives in Spain, as social niches, to contribute to a RES transition based on democratic, sustainable and decentralized production, as well as on social participation, ownership and management by citizens. Those agents who defend a slow change of the energy model, ensuring the capital interests of the fossil and nuclear business models, formed the "grey capital”, which plays a key role in the Spanish regime (Haas, 2016).

The evolution of the Spanish regime from the liberalization of the electricity sector in 1997 is described in section 3.1. This is the context where the RES cooperatives niche has emerged (section 3.2) and afterwards evolved to counteract the regime's resistance which, in the case of Spain, has been especially hostile (section 3.3).

\section{Development of RES cooperatives within the Spanish context}

This section analyzes the evolution of the RES cooperatives within the Spanish context, applying the MLP approach. The analysis is focused on the electric system, given that (1) Spanish RES cooperatives are mainly focused on the electricity market (see section 3.2), and (2) this is the only sector where the regime has to date considerably engaged in the promotion of RES in the country (see Figure 1).

means shaping dominant discourses covering what and how it is being discussed (e.g. media control); material strategies rely on technical capabilities and financial resources to improve the technical dimension of the regime; and institutional power is the influence that is rooted in political cultures, ideology and governance structures. 
Capellán-Pérez, Iñigo; Álvaro Campos-Celador; and Jon Terés-Zubiaga. "Renewable Energy Cooperatives as an Instrument towards the Energy Transition in Spain.” Energy Policy 123 (December 1, 2018): 215-29. https://doi.org/10.1016/j.enpol.2018.08.064.

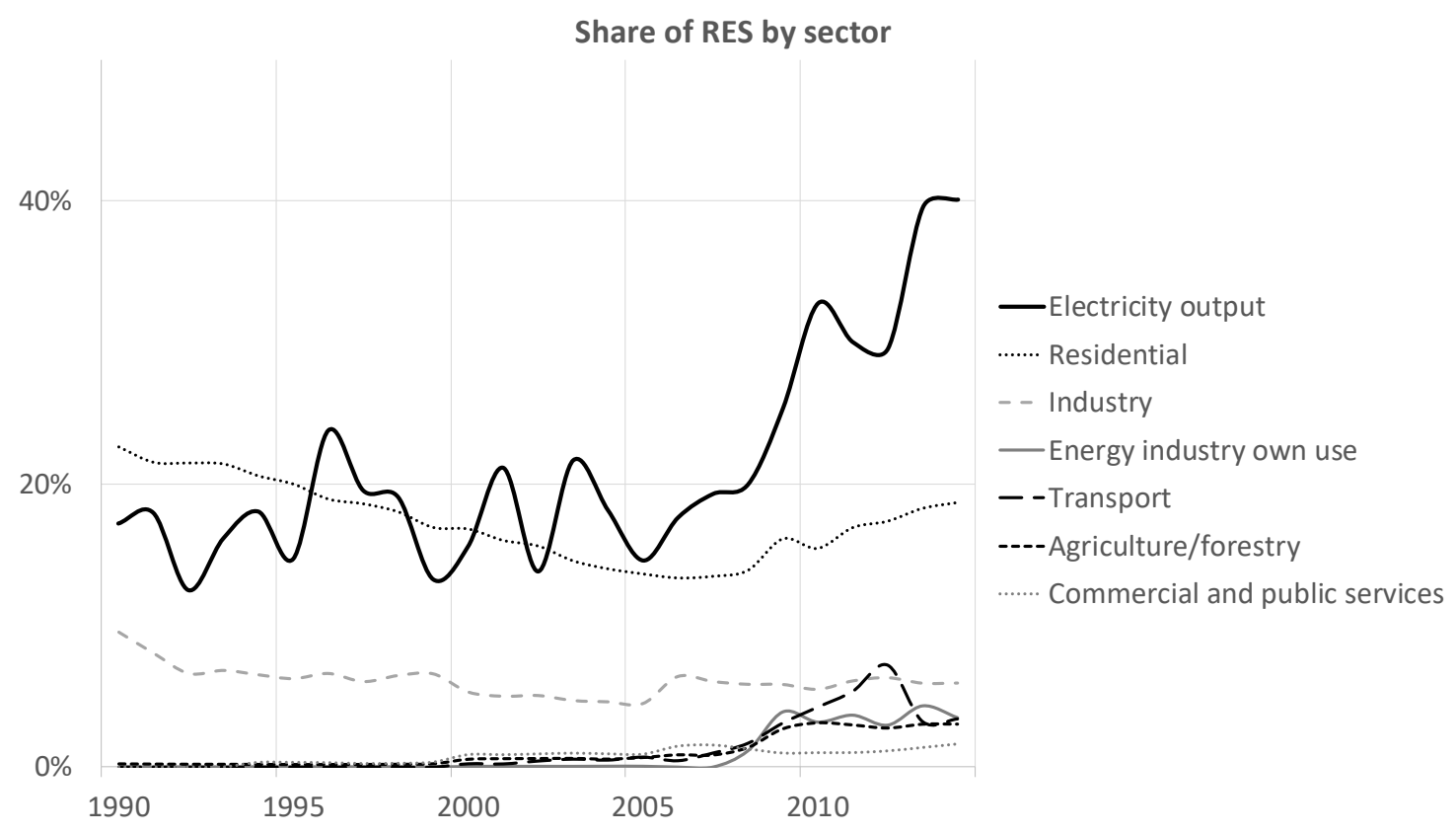

Figure 1: Share of RES by sector in Spain (1990-2014). Source: own work from IEA balances (IEA, 2016).

Oscillations in the share of electricity generation are due to the high variability of the hydroelectricity resource in the country.

In the remaining sectors, the Spanish regime has reinforced the reliance on non-renewable fuels by promoting the domestic extraction of unconventional gas, using fracking technologies, the project of converting Spain into a European natural gas hub, developing mega transport infrastructures that give priority to oil-based modes of transport, etc. (Aguilera Klink and Naredo Pérez, 2009; Bel et al., 2013; ODG, 2016). The promotion of biofuels cannot be seen as a sustainable policy given that, when accounting for indirect land use, the shift to biodiesel production in the EU is worse than fossil fuels in terms of GHG emissions (Laborde, 2011; Valin et al., 2015). In most cases, these policies form part of the broader European Union regime, where the Spanish regime operates.

This is also the case in most advanced industrialized countries, given that the transition to RES in the electricity sector presents several advantages, such as compatibility with existing transportation and distribution networks and the fact that most modern RES provide electricity (IPCC, 2014). 
Capellán-Pérez, Iñigo; Álvaro Campos-Celador; and Jon Terés-Zubiaga. "Renewable Energy Cooperatives as an Instrument towards the Energy Transition in Spain.” Energy Policy 123 (December 1, 2018): 215-29. https://doi.org/10.1016/j.enpol.2018.08.064.

\subsection{The Spanish electricity sector}

Considering the deployment of RES in the electricity sector, the Spanish regime can be practically split into two periods: a first period of regime promotion of RES (1997-2012, section 3.1.1) and a second one of regime resistance to RES (2012-onwards, section 3.1.2).

\subsubsection{Regime promotion of RES in the electricity sector (1997-2012)}

The management of the Spanish electric system radically changed from 1997 with the beginning of the liberalization process of the electricity sector. This change corresponded to the landscape shift enforced by the wave of neoliberalism that started in the 1970s and became hegemonic during the following decades. This brought many changes in the EU, such as the Maastricht Treaty (1992) and the project for a future European energy market. In this context, the Spanish Law 54/1997 transposed the EU Directive 96/92/CE, opening up the generation and retailing of electricity to competition, the technical and economic conditions of which were previously set up by the State. The national power transmission system was operated as a partly state-owned corporation (Red Eléctrica de España, REE), while the local distribution activity mostly remained as natural, regional monopolies from companies belonging to the UNESA association (UNESA refers to "Asociación Española de la Industria Eléctrica”, the association of the five traditional power utilities) (Riutort Isern, 2015). ${ }^{5}$

The new regulation also aimed to improve energy efficiency and promote electricity generation from technologies with lower environmental impacts. The so-called Special Regime (SR, Régimen Especial) was set up, including RES technologies (i.e. wind power, solar photovoltaic, solar CSP, small hydropower and biomass), energy recovery from waste and cogeneration (conventional plants were assigned to the Ordinary Regime, Régimen Ordinario). From the producer's point of view, electricity generation under the SR had priority access and financial

\footnotetext{
5 The companies belonging to UNESA are: Iberdrola, Endesa, Gas Natural - Fenosa, Viesgo - E.ON and EDP-HC (UNESA, 2014).
} 
Capellán-Pérez, Iñigo; Álvaro Campos-Celador; and Jon Terés-Zubiaga. "Renewable Energy Cooperatives as an Instrument towards the Energy Transition in Spain.” Energy Policy 123 (December 1, 2018): 215-29. https://doi.org/10.1016/j.enpol.2018.08.064.

incentives that made investment in these technologies attractive. From 1997 to 2012, successive regulations came into force (including support through a combined system of feed-in-tariffs and premiums between 2004 and 2012). Although some renewable power was installed before this process took place (mainly large hydro), it was within this new framework that the modern RES started to play a significant role in the country (Ciarreta et al., 2014; del Río González, 2008; Romero-Rubio and de Andrés Díaz, 2015).

From the consumer's point of view, although the electricity is mixed at the transportation level and purchased at the same hourly price (Ciarreta et al., 2014), since 2007 it is possible to certify that an amount equivalent to the electricity consumed has been generated from RES with the mechanism of Renewable Energy Certificates (RECs, Garantías de Origen), as a consequence of the transposition of the European legislation (2001/77/CE and 2009/28/CE Directives). ${ }^{6}$

Under this framework, the contribution of RES to the electricity generation of the country increased substantially. Figure 2A shows the sharp increase in wind capacity from the year 2000, and for solar capacity from 2006. RES generation from sources considered under the SR reached 30.5\% (33 MW) of the overall installed capacity and 27.5\% (72.4 TWh) of the overall electricity produced in 2015 (see Figure 2B) (REE, 2016a). By that year, wind reached $\sim 60 \%$ of the installed capacity in the SR (71\% of the RES without accounting for large hydro).

\footnotetext{
6 Thus, these RECs are annually recognized by the National Markets and Competition Commission to the RES producers who can transfer them to the retailing companies, which offer them to those consumers that demand electricity from RES. In Spain, RECs currently involve a cost as a consequence of the paperwork needed and the agents involved in that process. Although the cost of RECs is negotiated in each operation, it is currently close to $0.1 \mathrm{€} / \mathrm{MWh}$. Taking into account the fact that the average domestic consumption in Spain is about 3,000 kWh/year; this means that the annual cost for an average household electricity bill is then about $0.3 €$ (Marc Roselló (Som Energia), Personal Communication, 28-12-2016). The cost of RECs is still low, since the demand of electricity from renewable energy sources is much lower than the production from renewables. The non-regulated transferability of RECs has attracted attention from critics, who report that RECs do not distinguish between RE technologies and could lead to eventual cases of double accounting. Alternative REC voluntary systems have emerged to prevent this (Bürger, 2007). A detailed description of the Renewable Energy Certificates system in Spain is presented in (Marco, 2012).
} 
Capellán-Pérez, Iñigo; Álvaro Campos-Celador; and Jon Terés-Zubiaga. "Renewable Energy Cooperatives as an Instrument towards the Energy Transition in Spain.” Energy Policy 123 (December 1, 2018): 215-29. https://doi.org/10.1016/j.enpol.2018.08.064.

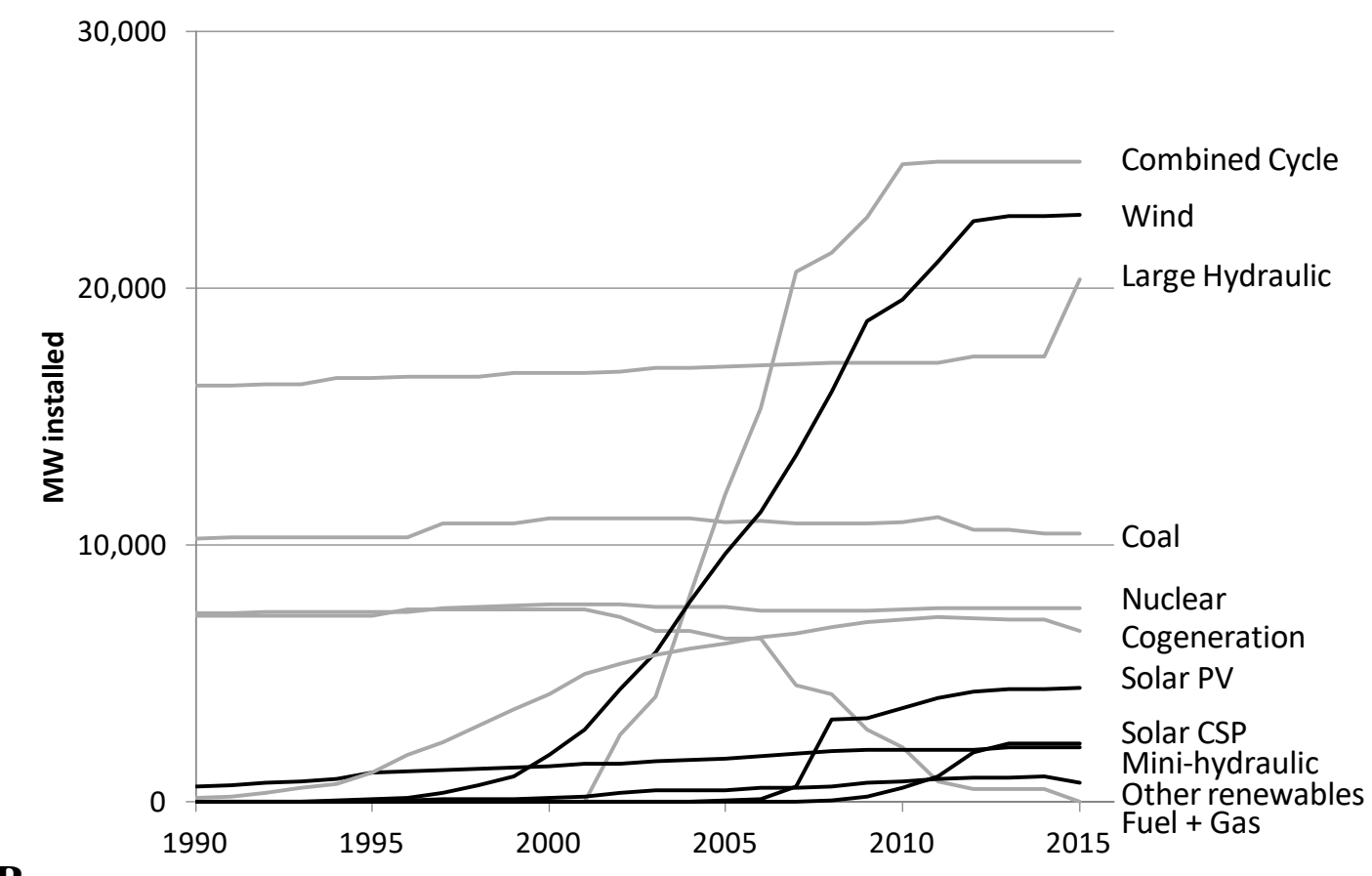

B

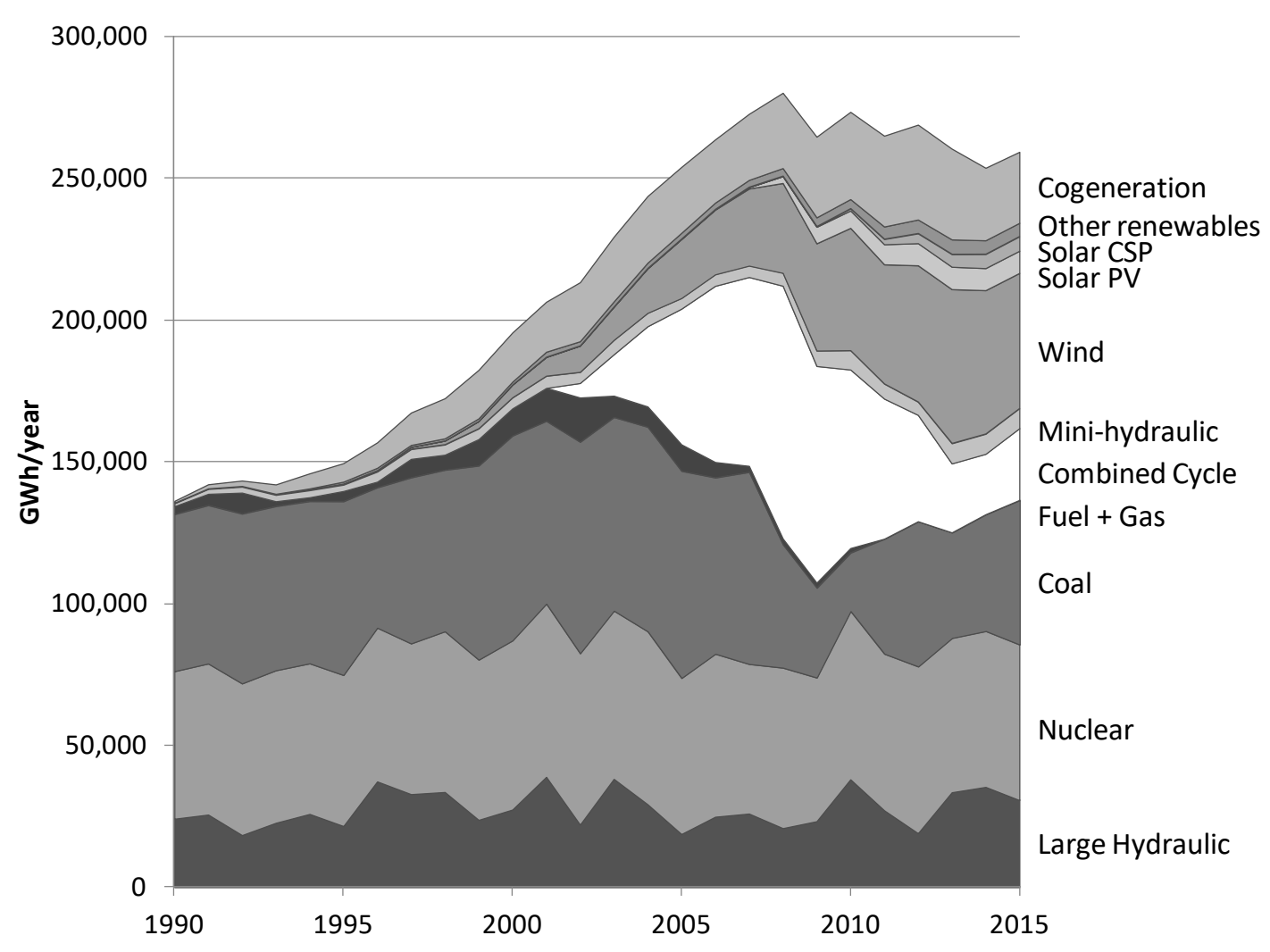

Figure 2: Evolution of the installed capacity (A, with RES in black) and electricity generation (B) by technology in peninsular Spain from 1990 to 2015. Other renewables include biogas, biomass, marine hydraulic and geothermal; also residues until 31/12/2014. Source: own work from (REE, 2016a). 
Capellán-Pérez, Iñigo; Álvaro Campos-Celador; and Jon Terés-Zubiaga. "Renewable Energy Cooperatives as an Instrument towards the Energy Transition in Spain.” Energy Policy 123 (December 1, 2018): 215-29. https://doi.org/10.1016/j.enpol.2018.08.064.

Although Spanish society supported the development of RES generation (EC, 2007a, 2007b), this was rather a passive attitude (Haas, 2016). Most RES generation capacity was promoted by the largest traditional companies in the electricity and construction sectors (see section 3.1.2 and (Romero-Rubio and de Andrés Díaz, 2015)). Indeed, no RES cooperative focusing on generation was created in this period, and only from 2010, when cooperatives where allowed to retail electricity (Romero-Rubio and de Andrés Díaz, 2015), new RES cooperatives were created in the country (see section 3.2).

Although some decreasing support to RES took place between 2008 and 2012, it was primarily a correction of disproportionate policy measures (Ciarreta et al., 2014; Haas, 2016). Thus, we consider the year 2012 as being the turning point from regime support to resistance in the deployment of RES in the electricity sector in Spain.

\subsubsection{Regime resistance to RES in the electricity sector (from 2012)}

The economic crisis broke the historical growth trend of electricity consumption in Spain $(+5 \%$ average per year from 1995 to 2008), leading to a reduction of around $10 \%$ in comparison to the historical maximum in 2008 (Figure 2B). During these years, in parallel to the promotion of new RES technologies, there was a surge in the installed capacity of gas combined cycle (GCC) by the largest traditional electricity companies. Figure 2A shows the increase in installed capacity in GCC from the early 2000s, which became the technology with the highest installed capacity in peninsular Spain in 2007 ( 25 GW). As a consequence of the large amount of installed capacity in parallel with a reduction in demand, the Spanish electric system resulted in a situation of large overcapacity. ${ }^{7}$ Since the electricity market gives priority to the generation from the SR, GCC currently covers less than $10 \%$ of electricity generation, with around $25 \%$ of the total installed

\footnotetext{
${ }^{7}$ Defining overcapacity in the electricity system for a given year as a ratio between the annual potential generation (installed capacity * $8760 \mathrm{~h} /$ year) and the annual electricity available for final consumption, the Spanish electricity system reached an overcapacity of 3.0 in 2008 (3.7 in 2015), while the EU-29 average was 2.5 the same year (2.8 in 2015), well above other countries, such as Germany (2.3 in 2008 and 2.8 in 2015), France (2.4 in 2008 and 2.5 in 2015) or UK (2.2 in 2008 and 2.5 in 2015) (Eurostat, 2018). See also: (del Río and Janeiro, 2016).
} 
Capellán-Pérez, Iñigo; Álvaro Campos-Celador; and Jon Terés-Zubiaga. "Renewable Energy Cooperatives as an Instrument towards the Energy Transition in Spain.” Energy Policy 123 (December 1, 2018): 215-29. https://doi.org/10.1016/j.enpol.2018.08.064.

capacity, generating just 25\% of the electricity supplied in 2008 (REE, 2016a). In other words, the GCC has been displaced from the electricity production market.

At this point of the analysis, it is relevant to analyze the ownership of electricity power plants in Spain by technology and utility in more detail. Figure 3 (see also Appendix B) shows that, by 2015, the five utilities associated in UNESA comprised over $80 \%$ of the installed capacity of the Ordinary Regime (100\% of nuclear, $97 \%$ of coal, $86 \%$ of large hydro and almost $80 \%$ of GCC), against just 31\% of RES. In relation to the latter, UNESA utilities have directed most of their RES investments to wind (91\%), their participation in other RES being very limited (remaining 9\%). As a result, UNESA owns almost 50\% of the wind power capacity installed in the country. In fact, the degree of ownership concentration depends on the technology; while for wind there is a high degree of ownership concentration (in 2014, 10 large energy companies owned approximately 73\% of the installed wind power capacity (AEE, 2016)), the PV sector is highly atomized, numerous installations exist and many facilities with power capacities below $100 \mathrm{~kW}$ are owned by small individual investors. As a result, the leading operators only have a small share (12.8\%) of the Spanish PV market ((DBK, 2014) cited by (Romero-Rubio and de Andrés Díaz, 2015)). 
Capellán-Pérez, Iñigo; Álvaro Campos-Celador; and Jon Terés-Zubiaga. "Renewable Energy Cooperatives as an Instrument towards the Energy Transition in Spain.” Energy Policy 123 (December 1, 2018): 215-29. https://doi.org/10.1016/j.enpol.2018.08.064.

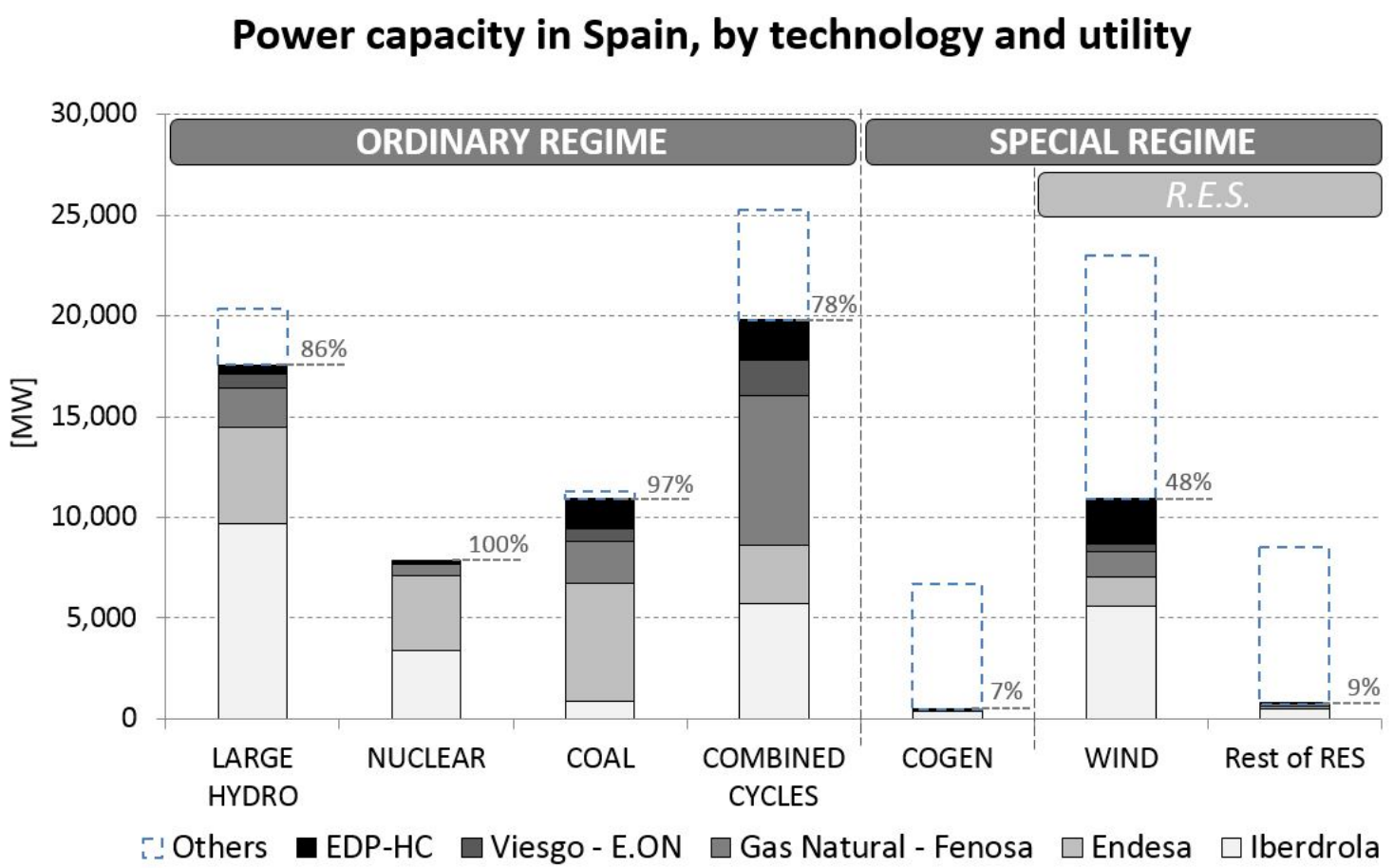

Figure 3: Estimation of the installed power capacity (MW) by technology and utility for the year 2015 in Spain.

Rest of RES includes: solar PV, solar CSP, biomass \& waste and mini-hydraulic. Sources: see Appendix B.

Furthermore, the economic downturn from the year 2007 evidenced that the liberalization process of the electricity market had failed in many aspects (Haas, 2016; Riutort Isern, 2015). Despite the Law 54/1997 enforcing the separation between operations of the different sectors of the electricity supply chain, traditional utilities have constituted clusters allowing them to cover all the economic activities from generation to the retailing of electricity in order to bypass the regulation. ${ }^{8}$ In 2013 , the traditional utilities coordinated in UNESA comprised: $72 \%$ of the generation, $98 \%$ of the distribution and $80 \%$ of the retailing of electricity in the country (UNESA, 2014). Spain's electricity system management is characterized by a lack of transparency: the transportation and distribution costs are currently self-audited by REE and the utilities and accepted by the State. Since the Government has the competence to set an upper limit to electricity tariffs, a mismatch

8 E.g. Iberdrola cluster ("Grupo Iberdrola”) comprises: "Iberdrola Generación España SA" for the production of electricity, "Iberdrola Distribución Eléctrica SA” for the distribution, "Iberdrola Clientes SA" for the retailing activity. 
Capellán-Pérez, Iñigo; Álvaro Campos-Celador; and Jon Terés-Zubiaga. "Renewable Energy Cooperatives as an Instrument towards the Energy Transition in Spain.” Energy Policy 123 (December 1, 2018): 215-29. https://doi.org/10.1016/j.enpol.2018.08.064.

can occur between the operation costs declared by the utilities and the prices paid by the consumers. In fact, this has happened since 2001, when the costs of the electric system started to increase and the Government decided to freeze the regulated tariffs while acknowledging the debt with the utilities. However, rather than an isolated case to protect consumers from a particular situation of high costs, this situation continued over the years (OCE, 2012). This accumulated deficit, known as Pricing Deficit, reached 26,000 million € in 2013 (UNESA, 2013).

The traditional utilities organized in UNESA took their opportunity and launched a campaign accusing the RES power plants (mainly those based on solar PV) of being responsible for the aforementioned Pricing Deficit due to the system of subsidies. As a consequence, a set of Royal Decrees have been approved over the last few years with catastrophic consequences for the RES sector in the country. It is worth noting that this campaign has been carried out with Governments from different political parties: the social-democrat PSOE (2008-2011) and the conservative PP (Dec. 2011 onwards). From 2012, subsidies to new RES installations were suppressed and the RE was finally abolished in 2014. The subsequent legislation strongly limits the economic feasibility of new RES projects and includes moratoriums and retroactive reductions on the existing incentives (Ciarreta et al., 2014; Haas, 2016; Riutort Isern, 2015; Romero-Rubio and de Andrés Díaz, 2015). ${ }^{9}$ Figure 2A shows how the capacity installed for all RES technologies in the country since 2012 has stalled.

Even though the policies to promote some of the RES technologies showed shortcomings (e.g. the system of incentives for solar PV was over-remunerated (Ciarreta et al., 2014)), it is not correct to allocate the Pricing Deficit solely to RES power plants. First, the mismatch started in 2001, when the RES share was still negligible. Second, the economic incentives to the SR also

\footnotetext{
${ }^{9}$ It should be noticed, nonetheless, that some renewable energy plants have been installed since 2012, being profitable in spite of the new barriers and the lack of bonuses. Additionally, there is the possibility for the in-situ production of renewable energy with independence from the electric market, i.e., RES selfconsumption. However, this option has also been politically blocked, a specific regulation for selfconsumption having not been set up until recently (Royal Decree 900/2015) and de facto preventing its development due to high restrictions included.
} 
Capellán-Pérez, Iñigo; Álvaro Campos-Celador; and Jon Terés-Zubiaga. "Renewable Energy Cooperatives as an Instrument towards the Energy Transition in Spain.” Energy Policy 123 (December 1, 2018): 215-29. https://doi.org/10.1016/j.enpol.2018.08.064.

included substantial subsidies to non-renewable energy resources, such as the energy recovery from waste (around $~ 50 \%$ coming from biomass) and cogeneration (mainly natural gas) (REE, 2016a). Third, the subsidies to the SR represent just a share of the total cost of the electricity system ( 35\% in 2012). Fourth, other circumstantial factors, such as the increase in oil prices, also drove fossil fuel and material prices to high levels during the 2000s. In fact, data for 2012 show that only $\sim 25 \%$ of the cost of the electricity system could be allocated to RES subsidies (CNE, 2013). Fifth, increasing the supply of electricity from the SR tends to lower the price of the market due to the merit-order effect (Azofra et al., 2014; Ciarreta et al., 2014; Gallego-Castillo and Victoria, 2015; Hildmann et al., 2013; Sáenz de Miera et al., 2008). Sixth, there are many costs in the system that are not transparent or fully justified, such as capacity costs, large benefits of already amortized power plants (windfall profits), the so-called "costs of the transition to competition”, etc. (ODG, 2015). Thus, the causes of this Pricing Deficit are manifold and until a public audit of all the operation costs of the electrical system is performed, it will not be possible to identify all the drivers and their relative importance (OCE, 2012). Meanwhile, the proposition of initiatives to publicly audit these operation costs have to date been prevented by the Spanish Parliament (Ortiz Castellví, 2013).

In the light of these facts, it could be argued that the traditional utilities from UNESA profited from the lack of transparency of the market, as well as from their oligopolistic power and connections with the political ruling parties, to promote a shift in Government policies from support towards obstruction to RES in order to protect their interests and safeguard their investments in fossil fuel (notably GCC) and nuclear power plants (in parallel, UNESA utilities also forced the implementation of both up-rating and lifetime extensions for existing nuclear power plants (Schneider et al., 2012)). Hence, the Spanish electric system is characterized by a strong collusion between the big energy companies and Government interests, which corresponds to the close alliance between business and policy makers. This collusion is very well exemplified by the "revolving door" phenomenon, where multiple examples exist of chair exchanges between ex-Government members from different parties and electric companies' administration positions 
Capellán-Pérez, Iñigo; Álvaro Campos-Celador; and Jon Terés-Zubiaga. "Renewable Energy Cooperatives as an Instrument towards the Energy Transition in Spain.” Energy Policy 123 (December 1, 2018): 215-29. https://doi.org/10.1016/j.enpol.2018.08.064.

(Bel et al., 2015; Haas, 2016; Riutort Isern, 2015). Even though it infringes upon the citizens, it ensures the economic success of those companies, which, in the official discourse, can be identified as of "public interest”. ${ }^{10}$

The four different dimensions of regime resistance identified by Geels (Geels, 2014) (see section 2) are observed in the process presented above. Coinciding with the widespread installation of new RES capacity (Figure 2), an unofficial campaign against them was carried out by the Government and the "grey capital”, arguing that RES were responsible for the high energy prices and Pricing Deficit (discursive form of resistance). In fact, the liberalization process brought an increase in electricity costs that was not immediately perceived by the consumers, since the system incurred a debt; its payment was delayed several years and the regime took the opportunity to place the responsibility on RES. As a result, from 2012 onwards, a set of increasingly restrictive Royal Decrees have been passed against them (instrumental form of resistance). All this contrasted with the economic benefits from RES in Spain that, in some cases, could even overcome the expenses of the bonus for their promotion by the merit-order effect. The endangered interests of GCC, caused by their low operation over the last few years (Figure 2B), were saved by enforcing "capacity payments” which, however, were found by a report from the European Commission likely to distort competition by unduly favoring particular producers or technologies (EC, 2016) (material form of resistance). At the same time, institutions have supported shale gas projects by modifying tax schemes (material form of resistance), as well as relaxing environmental constraints (instrumental). Additionally, the fact that the economic powers in Spain have traditionally been highly concentrated has resulted in a soft public response (institutional form of resistance).

10 This matches the fact that the Spanish companies have a profit margin of 6.78, much higher than the European average, 2.62. Although it should be noted that since these utilities are multinational corporations, they also obtain profits from their operations in other countries. For example, in the case of Iberdrola in 2014, just 20\% of the reported benefits came from its operations in Spain (Urkidi et al., 2015). 
Capellán-Pérez, Iñigo; Álvaro Campos-Celador; and Jon Terés-Zubiaga. "Renewable Energy Cooperatives as an Instrument towards the Energy Transition in Spain.” Energy Policy 123 (December 1, 2018): 215-29. https://doi.org/10.1016/j.enpol.2018.08.064.

Spain had the fourth highest electricity price for household consumers in the EU-28, as of the end of 2014 (Eurostat, 2018); having increased by 70\% since the liberalization process started in 1997. This fact implies rates of fuel poverty above 15\% (Tirado Herrero et al., 2014), and an estimated population at risk of falling into poverty of 28\% (Pye and Dobbins, 2015), in combination with the high rates of unemployment (20.8\% in December 2015) (Eurostat, 2018), that results in a very complex and deep-rooted social problem. This context, together with the social mobilizations around 15M (2011) in the country (Cameron, 2014), has allowed social awareness of the importance of energy issues to increase and public recognition of the failures of the energy system in Spain (Haas, 2016). These have ultimately stimulated the active participation of society in promoting RES, thus creating the conditions for the development of modern RES cooperatives in the country. In fact, energy cooperatives have historically been promoted by citizens and communities in times of crisis (Vansintjan, 2015).

\subsection{Spanish RES cooperatives niche}

Section 3.1 presented the socioeconomic context under which the Spanish RES cooperatives niche emerged and has to operate. This section describes the creation, organization and operation of the Spanish RES cooperatives.

Two important periods can be identified in Spain's recent history related to energy cooperatives: (1: first wave-cooperatives) the end of the $19^{\text {th }}$ and beginning of the $20^{\text {th }}$ centuries, when people from peripheral regions collaborated to supply electricity to their businesses and homes, as it was not a priority for the State or private investors to connect these areas to the national grid; and (2: second wave-cooperatives) from 2010 onwards, when different organizations focusing mainly on the retailing of electricity from RES have been created. While the first wave cooperatives were born out of necessity, the creation of the second wave organizations has been motivated by environmental and social concerns following other European examples (Riutort Isern, 2015, sec. 3.3). 
Capellán-Pérez, Iñigo; Álvaro Campos-Celador; and Jon Terés-Zubiaga. "Renewable Energy Cooperatives as an Instrument towards the Energy Transition in Spain.” Energy Policy 123 (December 1, 2018): 215-29. https://doi.org/10.1016/j.enpol.2018.08.064.

When Spain started its electrification process, the electricity supply system prioritized populated urban areas, not reaching many small, isolated rural areas throughout the state. Thousands of local organizations (mainly cooperatives and municipal utilities) emerged to fill this gap in a similar process to other countries (Vansintjan, 2015). As time went by, many of these local businesses were absorbed or merged to become part of the corporations from UNESA, while a minority persisted: around 300 organizations, most of them small, are currently estimated to remain in operation throughout the country (Benavente, 2016). Of these, just 21 are cooperatives, focusing mainly on local electricity distribution; a few generate their own electricity. After the electricity market liberalization, some of them also started to undertake the activity of electric power retailing, although without a particular focus on RES. However, some of them have recently shifted to $100 \%$ RES generation and retailing, such as Enercoop ${ }^{11}$ in the Community of Valencia, with around 14,000 members, which could be considered a type \#3 RES cooperative (i.e., fully integrated RES cooperative, see Appendix A for a typology of organizational models of RES cooperatives, following the classification from Rijpens et al., (Rijpens et al., 2013)) (Riutort Isern, 2015). The Federation of Electric Cooperatives from the Community of Valencia (FCECV), founded in 1983, and currently coordinating 9 organizations grouping over 21,500 household members, is also going through a process to retail 100\% RES (FCECV, 2016).

Even though some experiences of small organizations aiming to promote RES in Spain can be found during the last decades of the $20^{\text {th }}$ century, the emergence of the second wave of RES cooperatives coincided with the impact of the global financial crisis in the country, the increasing social awareness around energy issues and the modification of the regulation in 2010 that allowed cooperatives to retail electricity. The latter favored the beginning of the operation of RES cooperatives in the country, which required significantly lower initial investments than other RES-related activities, such as the construction of power plants. In this line, it is worth noting

\footnotetext{
${ }^{11}$ Not to be confused with the French RES cooperative Enercoop (http://www.enercoop.fr/).
} 
Capellán-Pérez, Iñigo; Álvaro Campos-Celador; and Jon Terés-Zubiaga. "Renewable Energy Cooperatives as an Instrument towards the Energy Transition in Spain.” Energy Policy 123 (December 1, 2018): 215-29. https://doi.org/10.1016/j.enpol.2018.08.064.

that, unlike other European countries, no cooperative focusing on RES generation was created in Spain during the period favorable to RES deployment before 2012 in the country (Riutort Isern, 2015; Romero-Rubio and de Andrés Díaz, 2015). ${ }^{12}$

The reasons for the late development of modern RES cooperatives in Spain in comparison to other European countries are diverse: (1) traditional high concentration of economic (private capital) power in the infrastructures and energy $\operatorname{sector}^{13}$ (e.g. UNESA, see Figure 3) (Aguilera Klink and Naredo Pérez, 2009; Riutort Isern, 2015; Tamames, 1967); (2) the absence of a culture of municipal electric companies in the country, distribution activities having historically been carried out by private capital (Riutort Isern, 2015); and (3) the fact that the promotion of RES between 2000 and 2010 was led by the "grey capital” in the absence of participatory projects (Haas, 2016). Although the oil shocks from the 1970s and the anti-nuclear movements were relevant in Spain, they did not lead to the emergence of RES cooperatives as in other European countries (Riutort Isern, 2015; Vansintjan, 2015).

However, different types of entities that could be labelled as RES cooperatives do exist nowadays in Spain. Their review and analysis is complicated by the fact that, unlike other countries (e.g. The Netherlands, Germany or England, Wales and Northern Ireland (CEE, 2017; Kampman et al., 2016)) a common database with centralized, homogenous and updated data does not exist. Some organizations present some of the requirements for being labelled as RES cooperatives (e.g. organizations such as the Fundación Terra or Ecooo have promoted the participation of citizens in the construction of RES power plants since the 2000s). Moreover, new organizations are emerging in different parts of the country which are difficult to evaluate due to the lack of public information. The aim of this section is thus not to develop a detailed review of all the RES cooperatives which can currently be found in Spain, but to refer to some of them so as to be able

\footnotetext{
12 A detailed description of the evolution of electricity cooperatives in Spain during the $19^{\text {th }}, 20^{\text {th }}$ and $21^{\text {st }}$ centuries can be found in (Riutort Isern, 2015, sec. 3.3)).

${ }^{13}$ (Riutort Isern, 2015) reports that already in 1930, 50\% of the capacity was owned by 5 companies, and $70 \%$ by ten.
} 
Capellán-Pérez, Iñigo; Álvaro Campos-Celador; and Jon Terés-Zubiaga. "Renewable Energy Cooperatives as an Instrument towards the Energy Transition in Spain.” Energy Policy 123 (December 1, 2018): 215-29. https://doi.org/10.1016/j.enpol.2018.08.064.

to identify the role of the RES cooperatives niche and potential towards the energy transition in Spain. In this sense, those organizations that belong to the European Federation of Renewable Energy Cooperatives (REScoop.eu) are taken as reference for this analysis, see Table 2.

Two different phases can be identified in this second wave so far (August 2018): the first phase encompasses the 2010-2012 period, when three cooperatives emerged after rather independent processes in different locations: Som Energia (2010, Girona, Catalonia), Zencer (2011, Málaga, Andalusia) and GoiEner (2012, Gipuzkoa, Basque Country). Som Energia, the first RES cooperative in the country, was created in 2010 by staff and students of the University of Girona, in collaboration with a recently created association, with the aim of promoting sustainable development projects involving citizen participation in the city (Riutort Isern, 2015, p. 132). The awareness that many RES cooperatives were already successfully operating in other European countries played a key role in its inception, given the uncertainties and complexities of being the first organization of this type in the country (Riutort Isern, 2015, pp. 114-115). The creation of Som Energia, Goiener and Zencer implied the emergence of the RES cooperative model in Spain (Riutort Isern, 2015, p. 115). Since 2012, following these models, and in cooperation with them to start their operation, other cooperatives have gradually been created in Spain (e.g. Nosa Enerxía in Galicia (2014) and EnergÉtica in Castile-and-Leon (2015)). These organizations generally follow the RES cooperative \#2 model, i.e., regional-national RES cooperatives that operate through a combination of volunteer and professional work covering mainly electricity retailing activities (Table 2) (see Appendix A). Barrizar (2013, Bizkaia, Basque Country), represents an exception to the RES cooperatives \#2 model, being a smaller cooperative focused on the generation, distribution and retailing of heat (through district heating) and electricity at local level.

Table 2 reviews the membership, number of contracts and main activities carried out by these organizations as derived from their websites and personal communications. Som Energia stands out, with almost 50,000 members and over 80,000 electricity contracts, followed by Goiener with around 9,000 members and over 11,000 contracts. As of the latest available data, the aggregate 
Capellán-Pérez, Iñigo; Álvaro Campos-Celador; and Jon Terés-Zubiaga. "Renewable Energy Cooperatives as an Instrument towards the Energy Transition in Spain.” Energy Policy 123 (December 1, 2018): 215-29. https://doi.org/10.1016/j.enpol.2018.08.064.

figures from the surveyed organizations surpass 60,000 members and 90,000 contracts (i.e. $<0.4 \%$ of the total of contracts in the country (CNMC, 2017)).

Table 2: Characteristics of Spanish RES cooperatives members of REScoop.eu (data as of August 2018 unless specified otherwise)

\begin{tabular}{lllllll}
\hline RES cooperative & Year & of & Members & Contracts & Activities & Type \\
& creation & & & & & \\
& & & & & (G, D, R) & \\
\hline Som Energia & 2010 & 49,814 & 79,512 & G, $\quad$ R & (electricity; & $\# 2$ \\
& & & & & efficiency) & \\
\hline Zencer & 2011 & $1,040^{c}$ & $1,258^{c}$ & G, R (electricity) & $\# 2$ \\
& & & & & & \\
& & & & & & \\
\hline Goiener & 2012 & 8,837 & 11,200 & R (electricity) & $\# 2$
\end{tabular}

\begin{tabular}{lccccc}
\hline Barrizar & 2013 & 24 & 27 & $\begin{array}{l}\text { G,D,R (heat; electricity; } \\
\text { efficiency) }\end{array}$ \\
& & & & R (electricity) & $\# 2$
\end{tabular}

\begin{tabular}{llllll}
\hline EnergÉtica $^{\mathrm{b}}$ & 2015 & 1118 & 1,313 & G, R (electricity) & \#2
\end{tabular}

Total RES - $\quad 61,401 \quad 93,850 \quad-$
cooperative

Share as total in - $\quad-\quad<0.4 \% \quad-$
Spain

Notes: Activities: G: Generation; D: Distribution; R: Retailing.

${ }^{a}$ Nosa Enerxía subcontracted the electricity retailing with Goiener at the start of operation. It is currently operating as an "independent" retailer.

bEnergÉtica temporarily subcontracts the electricity retailing to Som Energia.

'Data from October 2016. 
Capellán-Pérez, Iñigo; Álvaro Campos-Celador; and Jon Terés-Zubiaga. "Renewable Energy Cooperatives as an Instrument towards the Energy Transition in Spain.” Energy Policy 123 (December 1, 2018): 215-29. https://doi.org/10.1016/j.enpol.2018.08.064.

The economic viability of the RES cooperatives type \#2 in Spain depends on many factors (e.g. the volume of retailed electricity, the profitability of generation, etc.). Given the restrictive regulation in relation to new generation, the only viable business model is the electricity retailing model, critically depending on a large social base in the order of thousands of members. For this reason, the emerging cooperatives have reached collaborative agreements with the already established organizations until they reach a viable size.

\subsection{Evolution of Spanish RES cooperatives in a hostile context}

As described in previous sections, the Spanish regime shifted from support to resistance to RES from 2012 onwards. This forced RES cooperatives to adapt to the new context. Special attention is devoted in this section to Som Energia, given that it accounts for over $80 \%$ of membership and contracts of the organizations reviewed in the country (Table 2), and the diversity of responses to regime resistance this organization has developed.

Som Energia was the first Spanish RES cooperative and hence benefited from a longer operating period than other organizations when the regime promoted new RES generation in the electricity sector. From 2011 to the beginning of 2013, nine rooftop PV installations and a biogas power plant were installed (1.25 MW). These projects were funded by voluntary remittances to the social capital by the cooperative members, offering an economic profitability from 3 to 5\%. From 2012, as a consequence of regulatory changes, the installation of new RES power plants presented a limited economic feasibility that prevented Som Energia and the rest of Spanish RES cooperatives from projecting new RES power plants following this model. One exception can be found in this regard: in 2015, Som Energia purchased an already operating small hydroelectric power plant of 1 MW for $800,000 €{ }^{14}$ In 2016, owing to the cooperation agreement between Som Energia and

\footnotetext{
14 The required amount was collected in less than two hours. 205 cooperative members participated in the project. Aiming at a high share amongst members, a participation limit was fixed at 25,000 € per member.
} 
Capellán-Pérez, Iñigo; Álvaro Campos-Celador; and Jon Terés-Zubiaga. "Renewable Energy Cooperatives as an Instrument towards the Energy Transition in Spain.” Energy Policy 123 (December 1, 2018): 215-29. https://doi.org/10.1016/j.enpol.2018.08.064.

EnergÉtica, $18 \%$ of this plant was purchased by EnergÉtica, which operates mainly in Castileand-Leon, where the power plant is located.

In order to deal with the regulation shift and pursuing the objective of installing new RES capacity, in 2015 Som Energia launched the “Generation kWh” project, an innovative project allowing cooperative members to make investments on "energy-shares”, where the investment is returned in the form of energy consumption reduction in the energy bill, with no interest rates (i.e., interest zero loan), during the lifetime of the power plants built in this way. In this system, an energy return is guaranteed instead of a financial one (Riutort Isern, 2015). So far, nearly 3 million $€$ have been invested by 3,000 cooperative members and the first plant developed by this mechanism (a 2 MW PV plant) has been producing energy since the beginning of 2016 (GenerationkWh, 2017).

Moreover, the new regulation stated that RES power plants built and in operation prior to 2012 could still receive subsidies, although retroactively reducing them to an overall profitability of around 7\% (revisable every 6 years). This change meant that many private, small RES capacity owners could not earn enough revenue to cover the financial costs of their investment, heading towards ruin through lack of profitability, confiscated by banks, or sold at a loss to the so-called vulture-funds. ${ }^{15}$ This delicate situation, in fact, opened up a new window of opportunity for RES cooperatives: as they are made up of thousands of members, they have access to significant amounts of money without the need to incur in any debt with financial entities. In this context, the "Recupera el Sol” (Recover the Sun) project was launched at the start of 2015 by some local groups of Som Energia and Ecooo. Through small investments from citizens, this aims to "socialize" those solar power plants at risk, releasing the small, private investors. Hundreds of citizen contributions amounting to more than 2 million $€$ have been collected to date, which have allowed 8 PV power plants to be purchased (Som Energia, 2016). Both “Recupera el sol” and

\footnotetext{
15 e.g. the National Association of Photovoltaic Energy Producers ANPIER represents 62,000 affected
} families (http://anpier.org). 
Capellán-Pérez, Iñigo; Álvaro Campos-Celador; and Jon Terés-Zubiaga. "Renewable Energy Cooperatives as an Instrument towards the Energy Transition in Spain.” Energy Policy 123 (December 1, 2018): 215-29. https://doi.org/10.1016/j.enpol.2018.08.064.

“Generation kWh” projects back the words of (Doci et al., 2015): “in niches certain social groups can develop innovations, not only technological, but also social innovations: new strategies and practices that strengthen civil society and meet social goals”.

Another significant milestone related to the synergies between cooperatives and civil organizations is the collaboration of Som Energia in the project "Viure del aire del cell” (Living the air of the sky) (EOLPOP, 2017). This project consists of the installation of a citizens' shared ownership wind turbine (2.35MW), which is planned to be under full operation at the beginning of 2018. Although the model is common in other European countries, it will be the first wind turbine erected in Spain by this means.

In addition, RES cooperatives have helped to create and/or strengthen other organizations and movements with similar aims and principles, as well as to increase the visibility of different civil agents for social transformation. The Platform for a New Energy Model (Px1NME, Plataforma por un Nuevo Modelo Energético), founded in 2012, serves as an example. The platform's main goal is to connect different energy-related movements towards a democratic and renewable energy production and management model in Spain. The platform includes more than 400 organizations and agents, such as the aforementioned RES cooperatives, individual producers, investors and industry associations (UNEF, APPA, ANPIER), foundations such as "Fundación Renovables”, NGOs, and political parties (Haas, 2016; Px1NME, 2016). ${ }^{16}$

These actions, together with the social and political changes related to $15 \mathrm{M}$ that have occurred over the last few years (Cameron, 2014), have managed to bring the energy transition to the social agenda in Spain (Haas, 2016). Even though the pathway to a democratic, distributed and

\footnotetext{
${ }^{16}$ For example, the Px1NME collaborated in the creation of a documentary about the functioning of the Spanish electric system , which was broadcast in November 2012 in prime time on a private national TV station (Évole, 2012). The emission caused a virulent reaction from UNESA that almost managed to cancel the (very popular) programme (Mancinas-Chávez and Galán Linares, 2014). However, its emission and the subsequent scandal spurred the social awareness of the importance of energy issues and the public recognition of the failures of the energy system in Spain. Membership growth of RES cooperatives after this event saw a boost.
} 
Capellán-Pérez, Iñigo; Álvaro Campos-Celador; and Jon Terés-Zubiaga. "Renewable Energy Cooperatives as an Instrument towards the Energy Transition in Spain.” Energy Policy 123 (December 1, 2018): 215-29. https://doi.org/10.1016/j.enpol.2018.08.064.

sustainable RES transition remains closed by regulation, modest movements are taking place in different local governments and municipalities around the country. Thus, some have started to change their electricity contracts to RES cooperatives and, in some cases, they are currently developing studies directed towards improving the energy efficiency of their processes, increasing the renewable energy sources in their districts, and even assessing the possibilities of creating municipal entities to manage, on their own, their electric power retailing business.

\section{Discussion}

The discussion is divided into two main parts: section 4.1 analyses the potential of RES cooperatives as an instrument towards the energy transition in Spain; while section 4.2 focuses on the lessons which can be applied to other countries.

\subsection{Potential of RES cooperatives as an instrument towards the energy transition in Spain}

From the analysis of the evolution of Spanish RES cooperatives and their interaction with the regime, in this section, their potential as an instrument towards the transition to RES in Spain is discussed in terms of strengths, barriers and opportunities. Some features are derived from being social enterprises, others from being RES cooperatives and sharing common elements with other similar projects around the world, and the remaining ones stem from operating in the particular context of Spain.

\subsubsection{Strengths}

As in other countries where liberalization merely transformed the State regulated monopoly into an oligopoly, Spanish RES cooperatives to appear as more transparent and competitive actors in the context of oligopolistic market situations (Huybrechts and Mertens, 2014).

As is typically the case for grassroots organizations, Spanish RES cooperatives' membership is characterized by a high level of social and environmental awareness with the goal of fulfilling 
Capellán-Pérez, Iñigo; Álvaro Campos-Celador; and Jon Terés-Zubiaga. "Renewable Energy Cooperatives as an Instrument towards the Energy Transition in Spain.” Energy Policy 123 (December 1, 2018): 215-29. https://doi.org/10.1016/j.enpol.2018.08.064.

existing needs instead of creating new ones. This feature, typical of not-for-profit organizations, sets aside economic profitability (revenues are mainly dedicated to covering the operating costs and investment requirements), enhancing the stability and robustness of the cooperatives and providing higher resilience to unexpected events. In order to preserve their independence, the first years of operation of RES cooperatives (until profits are reached) often rely on voluntary work, which necessitates a large, motivated and well-educated social base. The organizational model of Spanish RES cooperatives successfully combines the double nature of enterprise and social movement, and could serve as a model for other socio-economic initiatives.

Spanish RES cooperatives have shown a remarkable capacity to adapt to different scales and eventualities and this has allowed them to endure in a hostile context. Some of the cooperatives were created before the regime shift in 2012, successfully adapting their strategy thereafter, whereas others were created during the period of regime resistance. Currently, Spanish RES cooperatives operate at different territorial scales; some having evolved over time, typically from a local initiative to a broader scale (regional and state-level). The latter is the case of Som Energia, which began as a local initiative in Girona (Catalonia) but has evolved to state-level ( $\sim 60$ autonomous local groups) as a consequence of the active membership spread across the entire country. On the other hand, innovative investment tools, such as the "Generation kWh" (Som Energia) or "Recupera el Sol" (Som Energia and Ecooo) projects, have been designed as a response to the regulation cutback to RES and have enabled RES capacity to increase in spite of everything (see section 3.3). Thus, Spanish RES cooperatives have also shown their resilience to regime resistance by the creation of new relations between different niches. These joint ventures have allowed the social participation in the energy transition to increase.

RES cooperatives increasingly collaborate between each other to find and create synergies as well as to share learning processes and experiences. This is exemplified by the cooperation of some of them operating in the electricity market (such as Som Energia and Enercoop), and by how new RES cooperatives, created during the period of regime resistance, began to operate by subcontracting the electricity retailing to already established cooperatives to facilitate their short- 
Capellán-Pérez, Iñigo; Álvaro Campos-Celador; and Jon Terés-Zubiaga. "Renewable Energy Cooperatives as an Instrument towards the Energy Transition in Spain.” Energy Policy 123 (December 1, 2018): 215-29. https://doi.org/10.1016/j.enpol.2018.08.064.

term financial viability (Nosa Enerxía with Goiener and EnergÉtica with Som Energia) or jointly running power plants (Valteína hydropower plant by Energética and Som Energia). Goiener has also supported the creation of new RES cooperatives by providing legal support and subcontracting their software for the management of the retailing of electric energy. As an example, a permanent collaboration framework of 17 cooperatives (8 cooperatives from the first wave and 9 from the second wave ${ }^{17}$ ) was formally set up in May 2016, the Unión de Cooperativas de Consumidores y Usuarios de Energías Renovables (UNCCUER, 2016). However, it is too early to assess the potential of this joint initiative, given the existing diversity of business and social approaches amongst the constituent cooperatives.

RES cooperatives have been pioneers in the deployment of RES in Spain, achieving key milestones such as the installation of the first modern wind turbine in 1984 (Ecotècnia) and the first solar PV power plant operating without subsidies (2016, Som Energia, GenerationkWh). From the demand-side, these organizations successfully contribute to the uptake of RES with community-based social marketing initiatives such as educational communication and social diffusion (Viardot, 2013). Spanish RES cooperatives have also demonstrated the capacity for spreading new ideas at both social and political levels, largely due to the political change that has taken place in Spain as result of the $15 \mathrm{M}$ movement. As an example, some cooperatives are collaborating with local governments to analyze the viability of the creation of municipal energy utilities (e.g. Pamplona, Vitoria). Moreover, RES cooperatives have promoted actions with local administrations to address fuel poverty.

Finally, Spain, due to its southern location, enjoys high levels of solar irradiance in comparison with most of the EU countries where RES cooperatives have a higher presence. This not only

17 Cooperatives from the first wave (from the FCECV): Grup Cooperativa Elèctrica d'Alginet, Electrodistribuidora de F.A. El Serrallo, Electrica de Chera, Electrica de Sot de Chera, Electrica de Meliana, Electrica de Vinalesa, Cooperativa Eléctrica de Castellar, S.C.V. and Electrica de Guadassuar. Cooperatives from the second wave: AEIOluz, Econactiva, EnergÉtica, Goiener, Megara, Nosa Enerxia, Solabria, Zencer and La Corriente. Som Energia is in the process of joining. 
Capellán-Pérez, Iñigo; Álvaro Campos-Celador; and Jon Terés-Zubiaga. "Renewable Energy Cooperatives as an Instrument towards the Energy Transition in Spain.” Energy Policy 123 (December 1, 2018): 215-29. https://doi.org/10.1016/j.enpol.2018.08.064.

eases the economic viability of the projects thanks to a lower levelized cost of electricity, but also allows for a significant potential contribution of solar resource to a $100 \%$ RES mix supply (Capellán-Pérez et al., 2017).

\subsubsection{Barriers}

Regime resistance from both the national and supra-national levels represents one of the main barriers that Spanish RES cooperatives have to deal with to prosper. Up to now, even though they have managed to adapt and progress, the regulation complicates the entrance and operation in the market of new RES cooperatives. This prevents the niche from growing, as well as delaying the professionalization of the cooperatives; a high and continued dependence on voluntary work risks hindering the long-term viability of the organization. The regulation also strongly limits the installation of new RES power capacity (including restrictions to self-consumption, which obstruct the decentralization of generation), which has meant that only a very small fraction of the retailed electricity is produced so far by the RES cooperatives themselves. Moreover, most of it is backed by RECs that, to date, lack demand and are currently transferred at a nearly negligible cost. An eventual higher demand for RECs in the future and a proper REC traceability system could compromise the capacity of RES cooperatives to back the full amount of their retailed electricity. The Spanish regime is also shaped by the efforts of the European Commission to bring about regulatory harmonization, which has recently managed to enforce an instrumental shift from feed-in-tariffs/premiums to competitive auctions. Auction systems risk discriminating small operators and citizen initiatives and may thereby negatively impact the whole process of decentralization (Beermann and Tews, 2015; Fell, 2017). Ultimately, the successful operation of energy cooperatives requires an appropriate legislative framework, policy environment and enabling conditions, including support measures (ILO, 2013).

Modern Spanish RES cooperatives have experienced a quasi-exponential growth in both membership and electricity retailing since their creation. Although this is usually interpreted as a sign of success, it presents some drawbacks to their potential contribution towards a democratic, sustainable and decentralized energy transition in the country. RES cooperatives emerged from a 
Capellán-Pérez, Iñigo; Álvaro Campos-Celador; and Jon Terés-Zubiaga. "Renewable Energy Cooperatives as an Instrument towards the Energy Transition in Spain.” Energy Policy 123 (December 1, 2018): 215-29. https://doi.org/10.1016/j.enpol.2018.08.064.

reduced group of people with active participation in meetings and face-to-face relationships. However, membership growth and territorial spread of RES cooperatives make the active participation of members more difficult and a greater level of professionalization and new tools are necessary to manage the participation that can no longer continue as conceived at the very beginning (Kunze and Becker, 2014). In addition, growth can induce risks of instrumentalization and denaturation as a result of the interaction with agents of the regime that could, eventually, cause a change in the operation following the logic of the regime. This risk is derived from the fact of being an organization in-and-against the market (Huybrechts, 2013), while surviving in the market might paradoxically imply identifying themselves with the growth and competition paradigm that, at least initially, is alien to them. For instance, Som Energia had to omit for the first time the sustainability criterion of not installing PV on land in order to accomplish the first plant of the "Generation kWh" project. The promotion of RES generation through traditional financial methods represent another risk. For example, Fleiß et al., (2017) analyzed two photovoltaic citizen participation initiatives in Austria, finding that the financial beliefs were the main driver behind joining such an initiative. This focus on financial gain clearly poses a risk in any attempted transition towards RES production, as it indicates that adopters may withdraw from participation as soon as a more attractive investment opportunity becomes available.

A critical barrier for the full energy transition to 100\% RES lies in the fact that Spanish RES cooperatives mainly focus on retailing electricity, which ultimately represents just a limited fraction (20-25\%) of the final energy of Spain (IEA, 2016). Moreover, the profit margin of retailing electricity in Spain is generally rather low $(\approx 5 \%)$, since most of the electricity bill is directed to covering regulated costs and taxes. Thus, it could be argued that, currently, most of the revenues of the cooperatives are in fact redirected to the regime structures (UNESA and the State) (ODG, 2015).

Despite their relatively fast growth, RES cooperatives still have a minor presence in the Spanish energy system. Together with legal, economic and technical barriers, cognitive barriers such as low knowledge and understanding of the cooperative model amongst politicians, bankers, 
Capellán-Pérez, Iñigo; Álvaro Campos-Celador; and Jon Terés-Zubiaga. "Renewable Energy Cooperatives as an Instrument towards the Energy Transition in Spain.” Energy Policy 123 (December 1, 2018): 215-29. https://doi.org/10.1016/j.enpol.2018.08.064.

potential partners and the general public are also a key obstacle faced by Spanish RES cooperatives, as happens at European level (Huybrechts and Mertens, 2014).

\subsubsection{Opportunities}

Spanish RES cooperatives have the potential to become a key agent in the transition process to a democratic, distributed and sustainable energy system in the country. This model presents clear advantages to tackle the global environmental crisis in relation to the technocratic approach based on centralized ownership and electricity generation, given that the sustainability crisis is both a technic and social challenge (Belda Miquel and Pellicer Sifres, 2016). This potential critically depends on their capability to spread the model across the country, both by increasing membership and economic activities of the existing cooperatives, and through the creation of new ones. Growth in membership provides benefits from being a stronger and more solid agent in the electric market, as well as increasing their capability to finance new RES projects, but this could drift into participation and representation problems. Hence, participation methods and tools should be regularly updated. These can be based on new technologies that increase access to information and allow the information to be channeled from the bases to the decision-making process. The active involvement of the members in other fields of the social economy eases the predisposition towards participation. Potential problems related to the growth dynamic of RES cooperatives could be counterbalanced by the internal reorganization of RES cooperatives to structure the decision-making in different spheres: technical, local, etc.

Growth in membership allows an increase in the capability of the cooperatives to finance new RES projects. Although the RES cooperatives currently assure the renewable origin of the electricity retailed through the RECs, the promotion of own generation would allow the members of the cooperative to directly contribute to the transition to a democratic, distributed and sustainable energy system. Moreover, this would allow the share of the revenues redirected to the regime structures to be reduced. 
Capellán-Pérez, Iñigo; Álvaro Campos-Celador; and Jon Terés-Zubiaga. "Renewable Energy Cooperatives as an Instrument towards the Energy Transition in Spain.” Energy Policy 123 (December 1, 2018): 215-29. https://doi.org/10.1016/j.enpol.2018.08.064.

Another way to expand the transformative potential of Spanish RES cooperatives would be to intensify the collaboration among them (e.g. developing the UNCCUER) and with other groups, associations, institutions and enterprises also involved in the democratic, distributed and sustainable bottom-up transition to RES (Belda Miquel and Pellicer Sifres, 2016; Bermejo, 2013). For example, collaboration with ethical banking may complement the funding of new generation projects given the high investments required; this collaboration may also ease the creation of new RES cooperatives, avoiding the current strong dependence on voluntary work in the early years. Collaboration with trade unions might also be a fertile area in the future, given that RES technologies are generally found to have higher employment-ratios than fossil and nuclear fuels (e.g. (Cartelle Barros et al., 2017)).

By socializing the energy issue and bringing it closer to the public, RES cooperatives have the potential to promote public debate about the transition to RES. In fact, this transition faces many challenges to achieve a democratic, equitable, distributed and sustainable energy system that could then be democratically discussed and managed, as opposed to the current dominant technocratic approach. From this debate, specific actions can be promoted to limit the negative implications of a mere technological shift to RES. This public debate could also be complemented by new knowledge based on independent research, since most of the related private research in the country is currently being directed by the "grey capital". Hence, Spanish RES cooperatives could play a significant role in promoting alternative analyses and discussions around the RES transition at national level (in a similar way to the federation REScoop.eu, which participates in many research projects at European level (REScoop, 2016)).

Most RES cooperatives in Spain currently deal exclusively with the retailing (and to a lesser extent also with the generation) of renewable electricity. Their activities could be expanded by focusing on energy efficiency improvements or promoting the electrification of some energy uses, such as electric mobility (e.g. Som Mobilitat and Ecotxe). Another alternative would be to expand the business to other types of final energy, less restricted by legal and technical external constraints, i.e., heating or cooling, which could help to increase the renewable energy use rate 
Capellán-Pérez, Iñigo; Álvaro Campos-Celador; and Jon Terés-Zubiaga. "Renewable Energy Cooperatives as an Instrument towards the Energy Transition in Spain.” Energy Policy 123 (December 1, 2018): 215-29. https://doi.org/10.1016/j.enpol.2018.08.064.

(Engelken et al., 2016). For instance, the high radiation levels in Spain make solar thermal collectors a very interesting technology for meeting heating and domestic hot water or even cooling by means of absorption refrigeration equipment. In any case, the promotion of new RES projects should follow the regional distribution of members as well as their energy demand. The distribution of electric energy may be another potential opportunity which would allow their presence in the electric system to increase; however, the current regulation does not facilitate this.

The main challenge is to confront the regime resistance to the transition to RES. In this aspect, the current strategy based on alliances between RES cooperatives and other agents has brought good results and should be strengthened (Belda Miquel and Pellicer Sifres, 2016). Since the regime cannot be destabilized from a single front and a close relationship with regime actors could promote denaturalization, new transversal niches promoting the transition to RES will have to emerge in order to change the regime. However, it is also likely that, in the next few decades, the landscape will put significant pressure on the regime globally as anthropogenic global environmental change continues to undermine the natural systems and processes that support human societies. If no vigorous and fast corrective actions are taken, the disruptive potential of future global environmental change may escalate to levels threatening human societies as we know them today through an increasing risk of reaching climate tipping points, massive migrations, hazardous inequality levels, etc. (Ahmed, 2017; Hansen and Sato, 2016; Lenton et al., 2008; Motesharrei et al., 2014; Steffen et al., 2015a, 2015b). Very different transition pathways may emerge in this context, e.g. overshoot and collapse, regional competition, sustainable degrowth, etc. (Demaria et al., 2013; Meadows et al., 2004; Raskin et al., 2010). Hence, further work may be directed to analyzing the interaction between RES cooperatives with the energy policy dynamics of the regime, distinguishing different transition pathways (Geels et al., 2016; Geels and Schot, 2007; Johanisova and Wolf, 2012). In particular, the role and strategies of bottom-up initiatives, such as RES cooperatives, should be studied in the context of top-down targets, such as the required energy decarbonization rates to avoid dangerous climate change and the design of a $100 \%$ RES energy mix to cope with the intermittency of RES. 
Capellán-Pérez, Iñigo; Álvaro Campos-Celador; and Jon Terés-Zubiaga. "Renewable Energy Cooperatives as an Instrument towards the Energy Transition in Spain.” Energy Policy 123 (December 1, 2018): 215-29. https://doi.org/10.1016/j.enpol.2018.08.064.

\subsection{Lessons from the experience of Spanish RES cooperatives}

The globally-interconnected challenges of the sustainability crisis (e.g. climate change) and fossil fuel depletion require active policies towards a fast RES transition in all countries of the globe in the coming decades. Given the current dominance of fossil fuels in the energy mix of most countries, regime resistance to this transition to RES will be frequent. If this transition is to be based on democratic, sustainable and decentralized production, RES cooperatives will have an essential role. However, with the exception of some Western and Northern European countries, this model is in a minority or does not exist at all (Kunze and Becker, 2014; REN21, 2016). In this context, the Spanish case is of special interest, given that, in the recent years, the RES cooperatives movement has arisen in a particularly hostile context.

However, ultimately, each country represents a particular case with a specific regulatory, cultural and social context: regulations, support systems and available financing; continued government support of existing energy players (including fossil fuels); local skills, knowledge, confidence and engagement of local populations, etc. In this sense, some of the particular strategies applied by Spanish RES cooperatives might eventually be applicable in other countries (ILO, 2013). Other EU-28 members where the RES cooperatives are not firmly established, such as other southern European countries, or almost absent, as is the case for central and eastern European countries (Kunze and Becker, 2014), may be able to profit more from the Spanish experience, given the common European regulatory framework. For example, Som Energia has been actively supporting the RES cooperatives Coopérnico of Portugal and Sifnos of Greece, as well as a collaboration of various cooperatives in the Netherlands. ${ }^{18}$ The case of Central and Eastern European countries is more complex, given that the concept of “cooperative” has been denigrated in those countries after the fall of the socialist systems in the early 1990s (Johanisova et al., 2014).

\footnotetext{
18 "Also dozens of initiatives from around the world which simply came to us with a few questions have been helped”. Personal communication from Gijsbert Huijink, Som Energia (10-12-2017).
} 
Capellán-Pérez, Iñigo; Álvaro Campos-Celador; and Jon Terés-Zubiaga. "Renewable Energy Cooperatives as an Instrument towards the Energy Transition in Spain.” Energy Policy 123 (December 1, 2018): 215-29. https://doi.org/10.1016/j.enpol.2018.08.064.

Research projects constitute another means of collaboration between RES cooperatives, e.g. REScoop.eu participates in several European research projects (REScoop, 2016).

In this section, we highlight a list of topics, from those discussed in section 4.1, where the case of Spanish RES cooperatives brings interesting lessons that can help build strategies to boost the expansion of this model elsewhere:

- Requirement of a strong social support base: The Spanish case shows that one of the main preconditions for the successful deployment of RES cooperatives lies in the existence of an informed and confident social base with strong and continued motivation to selflessly support the project over time, thus having the potential to overturn the hostile regulatory context.

- Liberalized energy markets: liberalized energy markets enable other agents, besides traditional energy utilities, to participate in the energy business, opening the door to such alternative social enterprises as not-for-profit cooperatives. Even though these markets are usually shaped for large and strong companies, RES cooperatives can also find their place under certain conditions.

- Innovative socio-technical solutions: RES cooperatives are social enterprises that share social motivations going beyond the market logic. Hence, these organizations can act as laboratories for innovative solutions. Innovation and resilience is vital to surviving in a hostile context.

- Development and expansion of organizations: RES cooperatives emerge from local initiatives and, depending on the objectives of each organization and the evolution of the regime and landscape, they can decide whether or not to grow in membership. Growth increases financial capacity which could be required to operate in the retailing market, build new RES infrastructure or hire staff. The latter point is critical, since the fulldependence on voluntary work compromises the long-term feasibility of the project. On the other hand, growth can affect the democratic basis of RES cooperatives, since it tends 
Capellán-Pérez, Iñigo; Álvaro Campos-Celador; and Jon Terés-Zubiaga. "Renewable Energy Cooperatives as an Instrument towards the Energy Transition in Spain.” Energy Policy 123 (December 1, 2018): 215-29. https://doi.org/10.1016/j.enpol.2018.08.064.

to complicate communication. Moreover, opening RES cooperatives to less motivated members requires a great effort to educate and communicate the philosophy and ideals upon which the cooperative is based on, otherwise the operation can be polluted by the logics of the regime they aim to challenge. Hence, active management of the growth of these organizations is crucial for them to prosper.

- Cooperation: Cooperation is essential for spreading the model proposed by RES cooperatives allowing a broader public to be reached, while also establishing alliances and creating a protected zone outside the regime. In this sense, two levels of cooperation should be distinguished, i.e, inwards (within cooperatives) and outwards. Inward cooperation allows changes in the regime to be promoted by bringing up a common agenda. Outward cooperation settles a flexible and ample collaboration network, where the ideas proposed by different organizations can flow in several directions. Large-scale socio-political movements provide great opportunities for setting up RES cooperatives and spreading the model.

- Diversification (energy \& beyond): Many RES cooperatives rely on existing energy infrastructure to start their activity, since it requires a lower initial investment. However, a potential exists for extending their operation to other services and activities. These can be within the electricity sector, including distribution activities or promoting electric mobility, or they can be through entry to other energy markets, such as heating and cooling production and distribution. This potential will depend on the existing infrastructure, the biophysical characteristics and the characteristics of the energy demand in specific locations.

\section{Conclusions and policy implications}

In Spain, the modern RES cooperative movement is at an early stage of development and has recently arisen as a reaction to a combination of factors: (1) the increasing awareness of the deficient liberalization of the electricity market still dominated by a reduced number of private 
Capellán-Pérez, Iñigo; Álvaro Campos-Celador; and Jon Terés-Zubiaga. "Renewable Energy Cooperatives as an Instrument towards the Energy Transition in Spain.” Energy Policy 123 (December 1, 2018): 215-29. https://doi.org/10.1016/j.enpol.2018.08.064.

companies, (2) the economic crisis from the year 2008, which has contributed to increasing the levels of fuel poverty, (3) the legal possibility of cooperatives to retail electricity only from 2010, (4) the increasing politicization of the energy issue from the 15M movement (2011), and (5) the shift of the Spanish Government’s policies against renewables from 2012 onwards. Spanish RES cooperatives have arisen in a volatile, hostile, economic and regulatory context which has induced specific organizational and operating structures. From the Multi-Level Perspective (MLP), renewable energy sources (RES) cooperatives have taken advantage of the pressure from the landscape (climate change, depletion of fossil fuels, economic crisis, regime shift in the country from RES promotion to resistance from 2012 onwards) to strengthen their niche: building networks, growing and maturing; showing a remarkable capacity to adapt to different scales and eventualities and to become a legitimated actor (Belda Miquel and Pellicer Sifres, 2016).

Despite the increase in RES electricity capacity in 1997-2012 in Spain, the power from traditional utilities and the "grey capital", which substantially increased fossil fuel capacity during the favorable period for RES, was not challenged. As a result, when the electric demand decreased due to the crisis and the conflict of interest arose, a systematic protection of the traditional utilities was carried out by the regime against RES.

The current regime resistance is identified as the main barrier that RES cooperatives have to deal with in order to prosper. Up to now, even though they have managed to adapt, the change in the RES regulation framework has strongly limited the installation of new RES power capacity. While this resistance prevails, the Spanish RES cooperatives niche has to learn to create new spaces where they can become stronger and, at the same time, facilitate the socio-political scenario that will make it possible to change the regime from within. In order to counteract the regime, it is also fundamental to overcome current cognitive barriers to project a public image that transmits the social, economic and environmental benefits of RES cooperatives for society. Other barriers include fast membership growth which challenges participation, and the risks faced by these hybrid models, combining alternative ways of doing things with integration in the extant economic landscape, which inevitably brings paradoxes. 
Capellán-Pérez, Iñigo; Álvaro Campos-Celador; and Jon Terés-Zubiaga. "Renewable Energy Cooperatives as an Instrument towards the Energy Transition in Spain.” Energy Policy 123 (December 1, 2018): 215-29. https://doi.org/10.1016/j.enpol.2018.08.064.

The discussion of the potential of RES cooperatives as an instrument towards a democratic, distributed and sustainable energy transition in Spain shows that they share some commonalities with other social enterprises, as well as other European RES cooperatives (from whom much can be learned due to their more advanced trajectories), together with specificities from the Spanish case. Amongst their strengths, Spanish RES cooperatives regularly collaborate to build synergies, as well as sharing learning processes and experiences, having built connections with other groups promoting a democratic, distributed and sustainable RES transition in Spain. They have also demonstrated their capacity to promote public debate about energy issues, as well as spreading new ideas at both social and political levels. RES cooperatives have a great potential to spread the model across the country, expanding their activities beyond the generation and supply of electricity, as well as to generate new knowledge based on independent research. Although the RES cooperatives niche thus has a key potential to contribute to a shift of the regime in the country, the MLP approach shows that the transition to a democratic, distributed and sustainable energy system requires systemic changes in different spheres (policies, infrastructures, education, values, habits, etc.). Hence, such social enterprises as RES cooperatives should not be seen as "solutions" on their own, but rather as laboratories of alternative economic practices and as one of many pillars on which alternative economies can be conceived and built (Horvat, 1982; Huybrechts, 2013). For further analysis, the need to create a common database with centralized, homogenous and updated data that would allow the evolution of the Spanish RES cooperatives to be monitored has been identified.

Despite the relatively fast growth and territorial spread of Spanish RES cooperatives in the last few years, they still have a minor presence in the country's energy system: as of the latest available data, the aggregate figures from the surveyed organizations in this work surpass 60,000 members and 90,000 electricity contracts, which is however $<0.4 \%$ of the total of contracts in the country. The RES cooperatives model has to substantially spread and increase in membership, retailing and energy production in order to contribute to pushing the regime towards a democratic, distributed and sustainable RES transition. If current trends of collaboration between them and 
Capellán-Pérez, Iñigo; Álvaro Campos-Celador; and Jon Terés-Zubiaga. "Renewable Energy Cooperatives as an Instrument towards the Energy Transition in Spain.” Energy Policy 123 (December 1, 2018): 215-29. https://doi.org/10.1016/j.enpol.2018.08.064.

integration within other transformative groups and society are maintained and deepened, the experience in other European countries shows that the window of opportunity is large.

From the perspective of policy making, a number of policies might stimulate the emergence and development of RES cooperatives. These can be direct and indirect promotional measures. Direct promotional measures include, for example, specific loans or guarantees schemes, technical assistance and capacity-building, including partnerships with government agencies, actions to disseminate the benefits of the cooperative model for the management of energy, etc. Indirect promotional measures include the promotion of RES, eco-social requisites in public tenders, etc. In the Spanish case, the regional/local level could partially counteract the regime resistance at national level to the RES transition based on democratic, sustainable and decentralized production. Lowering of burocratic burdens at all scales will ease the successful operation of RES cooperatives, given that that regulation on energy production and distribution favour large enterprises. For example, feed-in-tariffs are a more appropriate system to stimulate the development of local, small-scale new RES power plants than auction systems (Beermann and Tews, 2015; Fell, 2017). In summary, the successful operation of energy cooperatives requires a flexible and conducive legislative framework, policy environment and enabling conditions, including support measures (ILO, 2013).

The globally interconnected challenges of the sustainability crisis (e.g. climate change) and fossil fuel depletion require active policies towards a fast RES transition in all countries around the globe in the coming decades. Given that the sustainability crisis is both a technic and social challenge, this cooperative model presents clear advantages in relation to the technocratic approach based on centralized ownership and electricity generation. However, in most countries, the energy regime is reluctant to welcome the RES transition based on democratic, sustainable and decentralized production. Hence, the case of RES cooperatives in Spain can serve as inspiration to other countries where the RES cooperatives are currently not firmly established or the model does not exist at all. 
Capellán-Pérez, Iñigo; Álvaro Campos-Celador; and Jon Terés-Zubiaga. "Renewable Energy Cooperatives as an Instrument towards the Energy Transition in Spain.” Energy Policy 123 (December 1, 2018): 215-29. https://doi.org/10.1016/j.enpol.2018.08.064.

\section{Acknowledgements}

We would like to thank Ortzi Akizu, Roberto Bermejo, Gorka Bueno, Leire Gorroño, Tobias Haas, Konrad Kunze, Victoria Pellicer and Rodrigo J. Ruíz García for comments and feedback during the writing process of the paper. Also Iñaki Gaztelu, and José Luis Torres Coca for facilitating the data about the cooperatives Barrizar and Zencer, respectively. A preliminary version of this paper was presented at the $5^{\text {th }}$ International Degrowth Conference in Budapest (2016).

This work has been partially developed under the MEDEAS project, funded by the European Union’s Horizon 2020 research and innovation programme under grant agreement No 691287. Iñigo Capellán-Pérez also acknowledges financial support from the Juan de la Cierva Research Fellowship of the Ministry of Economy and Competitiveness of Spain (no. FJCI-2016-28833)

\section{Appendices}

\section{Appendix A}

Table A1: Organizational modes of RES cooperatives from Rijpens et al., (Rijpens et al., 2013).

$\begin{aligned} & \text { \#1: Local group of } \\ & \text { citizens }\end{aligned}$
and therefore, commonly with no perspective of growth. They operate
on a local basis by the volunteer work of the members who, at the same
time, are the only investors of the RES cooperative. This typology is
commonly referred to as RES community projects (Romero-Rubio and
de Andrés Díaz, 2015) and can mainly be regarded as internally
oriented niches with a more limited regime transformation potential.


Capellán-Pérez, Iñigo; Álvaro Campos-Celador; and Jon Terés-Zubiaga. "Renewable Energy Cooperatives as an Instrument towards the Energy Transition in Spain.” Energy Policy 123 (December 1, 2018): 215-29. https://doi.org/10.1016/j.enpol.2018.08.064.

However, as niches, they have the capacity to scale-up and trigger substantial changes (Doci et al., 2015).

\#2: $\quad$ Regional- Started by a group of citizens with an internal or external motivation national RES and presents a bottom-up spread developing several renewable energy cooperative projects. They operate at a regional-national basis by the mix of volunteer work of the members and work of the employees. They cover generation and/or retailing activities. Financial sources come from the members, but can also present external investors. On occasions, RES cooperative \#2 can come from the evolution of RES cooperative \#1. In comparison to RES cooperative \#1, they show a more externally oriented nature, most of them having a democratic and distributed RES transition amongst their objectives.

\#3: Fully integrated RES cooperatives that own and control the whole supply chain: RES cooperative production, distribution and consumption, which means partial independence from the utilities and regulative constraints. They are usually long-established cooperatives that have commonly evolved from a RES cooperative \#1 and \#2, since the full integration of the energy supply chain presents more limitations nowadays, owing to the presence of big companies with a virtual monopoly of parts of that chain.

\#4: Network of RES As its name indicates, it consists of the integration/coordination of cooperatives several RES cooperatives. Once an organizational and operational structure is conceived, this is shared at different locations by a common root, maintaining links with the aim of optimizing the operation and a balance between scales of economies, time and resources. Thus, this common ground provides stabilization through sharing learning 
Capellán-Pérez, Iñigo; Álvaro Campos-Celador; and Jon Terés-Zubiaga. "Renewable Energy Cooperatives as an Instrument towards the Energy Transition in Spain.” Energy Policy 123 (December 1, 2018): 215-29. https://doi.org/10.1016/j.enpol.2018.08.064.

processes and generic rules. One example is Energy4All in the UK, which is formed by 20 cooperatives.

\#5: $\quad$ Multi- $\quad$ The RES cooperative is not only formed by individual members, but stakeholder also includes other agents of the energy supply chain such as

governance model consumers, producers, workers, communities, partners, etc., which clutters the governance structure. This RES cooperative type can exist at different levels, from the local to the regional. One example of this type is Enercoop in France, which is formed by 10 regional cooperatives that are integrated at the national level. In short, it can be stated that type \#4 is based on horizontal integration, whereas type \#5 seeks vertical integration.

\begin{abstract}
\#6: Non-energy- Organizations that operate beyond the scope of renewable energy,
focused under specific conditions, decide to set up a renewable energy project organization as complementary to their main activity. The structure of that organization is commonly reproduced in the management of the project. In a way, similarities in the scale can be found with RES cooperative \#1, but they have a very different origin and motivation.
\end{abstract}

$\overline{\text { Notes: According to (Doci et al., 2015), niches can be externally or internally oriented. Internally }}$ oriented are more focused on satisfying a need rather than explicitly aiming at a regime transformation, which would correspond to externally oriented niches. 
Capellán-Pérez, Iñigo; Álvaro Campos-Celador; and Jon Terés-Zubiaga. "Renewable Energy Cooperatives as an Instrument towards the Energy Transition in Spain.” Energy Policy 123 (December 1, 2018): 215-29. https://doi.org/10.1016/j.enpol.2018.08.064.

\section{Appendix B}

Table B1 shows the estimation of installed power capacity in Spain by technology and utility for the year 2015. Related data are highly dispersed and inconsistencies among different sources (REE, utilities, business associations, etc.) can often be found. For this reason, with the aim of ensuring the accuracy and consistency of the estimations, all the publicly available sources reporting data known to the authors have been used and compared to check their reliability. Those sources include:

- IRENA (The International Renewable Energy Agency), to obtain RES power capacity in Spain by technology (IRENA db, 2017).

- AEE (Asociación Empresarial Eólica, Spanish Wind Energy Association), to obtain the Wind energy capacity in Spain and the ownership of these installations (AEE, 2016).

- REE (Red Electrica de España, the company involved in electricity system operation and transport in Spain), to obtain the power capacity in Spain by technology (REE, 2016b).

- UNESA (Asociación Española de la Industria Eléctrica, the association of the five largest power utilities in Spain), where aggregated data of power capacity by technology of the five UNESA-Utilities have been obtained (UNESA, 2015).

- Spanish Ministry of Energy, Tourism and the Digital Agenda, where detailed data about Nuclear Power Capacity in Spain and the ownership of each nuclear plant have been obtained.

- OCE (Observatorio Crítico de la Energía), to obtain detailed data about Coal power capacity in Spain and the ownership of each coal power plant in Spain (OCE, 2016).

- Corporative information available on the webpages of the five UNESA-Utilities (Iberdrola, Endesa, Gas Natural - Fenosa, Viesgo - E.ON and EDP-HC), to obtain general data about power capacity installed by technology by each utility.

- Data and other information published in different news sources and journals about energy issues have been used to verify the consistency of the estimation. 
Capellán-Pérez, Iñigo; Álvaro Campos-Celador; and Jon Terés-Zubiaga. "Renewable Energy Cooperatives as an Instrument towards the Energy Transition in Spain.” Energy Policy 123 (December 1, 2018): 215-29. https://doi.org/10.1016/j.enpol.2018.08.064.

Energy from waste has been included in "Rest of RES”. However, it must be highlighted that according to REE, energy from waste is considered to be a $50 \%$ renewable source. In any case, currently installed energy-from-waste power capacity in Spain is still negligible compared to total power capacity (there are 11 plants operating in Spain), and none of them are owned by UNESAutilities.

Table B1: Estimation of installed power capacity (MW) in Spain by technology and UNESA-utility for the year 2015. Rest of RES includes: solar PV, solar CSP, thermal renewable, biomass \& waste and mini-hydraulic. (Sources: data collated from (AEE, 2016; IRENA db, 2018; OCE, 2016; REE, 2016b; UNESA, 2015), and the webpages of UNESA-utilities (EDP Energía, 2016; ENDESA, 2016; Gas Natural-Fenosa, 2016; Iberdrola, 2016; Viesgo, 2016). 


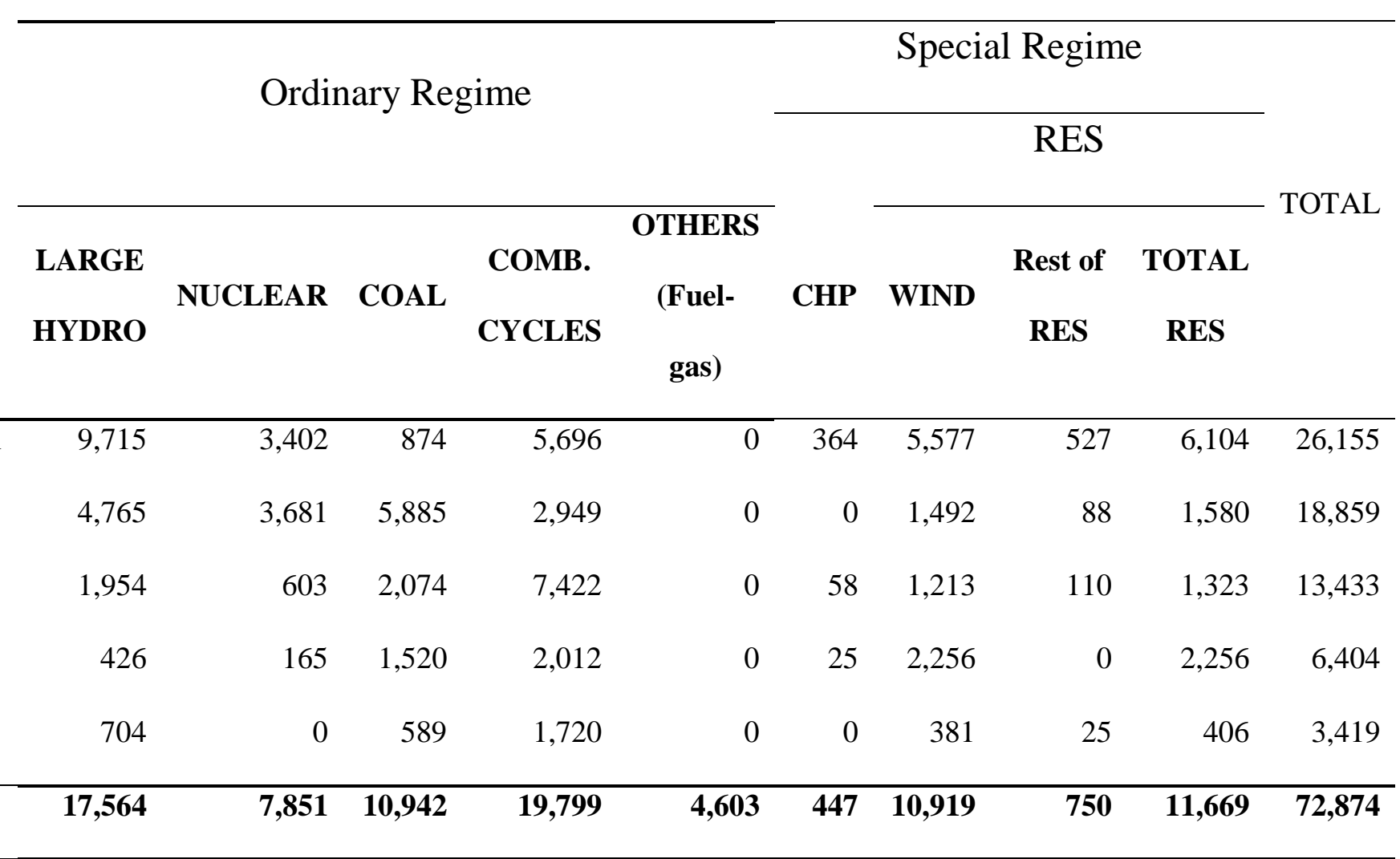

\begin{tabular}{ccccccccccc}
\hline TOTAL IN SPAIN & 20,353 & 7,851 & 11,262 & 25,287 & 4,603 & 6,728 & 23,003 & 8,493 & 31,496 & 107,580 \\
& & & & & & & & & & \\
\% UNESA & $\mathbf{8 6 . 3 \%}$ & $\mathbf{1 0 0 . 0 \%}$ & $\mathbf{9 7 . 2 \%}$ & $\mathbf{7 8 . 3 \%}$ & $\mathbf{1 0 0 . 0 \%}$ & $\mathbf{6 . 6 \%}$ & $\mathbf{4 7 . 5 \%}$ & $\mathbf{8 . 8 \%}$ & $\mathbf{3 7 . 0 \%}$ & $\mathbf{6 7 . 7 \%}$ \\
\hline
\end{tabular}


Capellán-Pérez, Iñigo; Álvaro Campos-Celador; and Jon Terés-Zubiaga. "Renewable Energy Cooperatives as an Instrument towards the Energy Transition in Spain.” Energy Policy 123 (December 1, 2018): 215-29. https://doi.org/10.1016/j.enpol.2018.08.064.

\section{References}

AEE, 2016. Eólica 2016. Asociación Empresarial Eólica (Spain).

Agterbosch, S., Vermeulen, W., Glasbergen, P., 2004. Implementation of wind energy in the Netherlands: the importance of the social-institutional setting. Energy Policy 32, 2049-2066. https://doi.org/10.1016/S0301-4215(03)00180-0

Aguilera Klink, F., Naredo Pérez, J.M., 2009. Economía, poder y megaproyectos. Fundación César Manrique, Lanzarote (España).

Ahmed, N.M., 2017. Failing States, Collapsing Systems, SpringerBriefs in Energy. Springer International Publishing, Cham.

Avila, S., 2018. Environmental justice and the expanding geography of wind power conflicts. Sustain. Sci. 1-18. https://doi.org/10.1007/s11625-018-0547-4

Azofra, D., Jiménez, E., Martínez, E., Blanco, J., Saenz-Díez, J.C., 2014. Wind power merit-order and feed-in-tariffs effect: A variability analysis of the Spanish electricity market. Energy Convers. Manag. 83, 19-27. https://doi.org/10.1016/j.enconman.2014.03.057

Barca, S., 2011. Energy, property, and the industrial revolution narrative. Ecol. Econ., Special Section: Ecological Economics and Environmental History 70, 13091315. https://doi.org/10.1016/j.ecolecon.2010.03.012

Becker, S., Kunze, C., 2014. Transcending community energy: collective and politically motivated projects in renewable energy (CPE) across Europe. People Place Policy 8, 180-191.

Beermann, J., Tews, K., 2015. Preserving Decentralised Laboratories for Experimentation under Adverse Framework Conditions.

Bel, G., Estache, A., Foucart, R., 2013. 10. Transport infrastructure failures in Spain: mismanagement and incompetence, or political capture?, in: Soreide, T., Williams, A. (Eds.), Corruption, Grabbing and Development: Real World Challenges, Real World Challenges. Edward Elgar Publishing, UK, USA, p. 129.

Bel, G., González-Gómez, F., Picazo-Tadeo, A., others, 2015. Political connections, corruption, and privatization of public services: Evidence from contracting out water services in Spain. University of Barcelona, Research Institute of Applied Economics.

Belda Miquel, S., Pellicer Sifres, V., 2016. Repensando el cambio climático desde la innovación social de base: aproximaciones desde el desarrollo humano y las transiciones socio-técnicas. III Congreso Internacional de Estudios del Desarrollo (2016).

Benavente, R.P., 2016. Las 300 pequeñas eléctricas que aún plantan cara a las grandes del sector. El Confid.

Bermejo, R., 2013. Ciudades postcarbono y transición energética. Rev. Econ. Crítica 215-243.

Boon, F.P., Dieperink, C., 2014. Local civil society based renewable energy organisations in the Netherlands: Exploring the factors that stimulate their emergence and development. Energy Policy 297-307. https://doi.org/10.1016/j.enpol.2014.01.046

Bürger, V., 2007. Green Power Labelling. An Instrument to Enhance Transparency and Sustainability on the Voluntary Green Power Market, Final Report of the CLEAN-E. ed. Öko-Institut, Freiburg. 
Capellán-Pérez, Iñigo; Álvaro Campos-Celador; and Jon Terés-Zubiaga. "Renewable Energy Cooperatives as an Instrument towards the Energy Transition in Spain.” Energy Policy 123 (December 1, 2018): 215-29. https://doi.org/10.1016/j.enpol.2018.08.064.

Cameron, B., 2014. Spain in crisis: 15-M and the culture of indignation. J. Span. Cult. Stud. 15, 1-11. https://doi.org/10.1080/14636204.2014.1002601

Capellán-Pérez, I., de Castro, C., Arto, I., 2017. Assessing vulnerabilities and limits in the transition to renewable energies: Land requirements under $100 \%$ solar energy scenarios. Renew. Sustain. Energy Rev. 77, 760-782. https://doi.org/10.1016/j.rser.2017.03.137

Capellán-Pérez, I., Mediavilla, M., de Castro, C., Carpintero, Ó., Miguel, L.J., 2014. Fossil fuel depletion and socio-economic scenarios: An integrated approach. Energy 77, 641-666. https://doi.org/10.1016/j.energy.2014.09.063

Cartelle Barros, J.J., Lara Coira, M., de la Cruz López, M.P., del Caño Gochi, A., 2017. Comparative analysis of direct employment generated by renewable and nonrenewable power plants. Energy 139, 542-554. https://doi.org/10.1016/j.energy.2017.08.025

CEE, 2017. Community energy state of the sector. A study of community energy in England, Wales and Northern Ireland. Community Energy England.

Ciarreta, A., Espinosa, M.P., Pizarro-Irizar, C., 2014. Is green energy expensive? Empirical evidence from the Spanish electricity market. Energy Policy 69, 205215.

CNE, 2013. Memoria de actividades 2012. Comisión Nacional de Energía, Madrid.

CNMC, 2017. Boletín de Indicadores Eléctricos de Noviembre de 2017. Comisión Nacional de los Mercados y la Competencia.

DBK, 2014. Estudio sectores de DBK. Energías renovables. $7^{a}$ edición.

de Castro, C., Mediavilla, M., Miguel, L.J., Frechoso, F., 2013. Global solar electric potential: A review of their technical and sustainable limits. Renew. Sustain. Energy Rev. 28, 824-835. https://doi.org/10.1016/j.rser.2013.08.040

DEA, 2017. Regulation and planning of district heating in Denmark (Technical Report). Danish Energy Agency, https://ens.dk/, Denmark.

Debor, S., 2014. The Socio-Economic Power of Renewable Energy Production Cooperatives in Germany. Wupperthal Papers.

del Río González, P., 2008. Ten years of renewable electricity policies in Spain: An analysis of successive feed-in tariff reforms. Energy Policy 36, 2917-2929. https://doi.org/10.1016/j.enpol.2008.03.025

del Río, P., Janeiro, L., 2016. Overcapacity as a Barrier to Renewable Energy Deployment: The Spanish Case. J. Energy 2016. https://doi.org/10.1155/2016/8510527

Demaria, F., Schneider, F., Sekulova, F., Martinez-Alier, J., 2013. What is Degrowth? From an Activist Slogan to a Social Movement. Environ. Values 22, 191-215. https://doi.org/10.3197/096327113X13581561725194

Doci, G., Vasileiadou, E., Petersen, A.C., 2015. Exploring the transition potential of renewable energy communities. Futures 66, 85-95.

EC, 2016. Interim Report of the Sector Inquiry on Capacity Mechanisms (Report from the Commission No. C(2016) 2107 final). European Commission, Brussels.

EC, 2007a. Energy Technologies: Knowledge, Perception, Measures (Special Eurobarometer). Eurobarometer, European Commission.

EC, 2007b. Attitudes on issues related to the EU energy policy (No. 206a), Flash EB Series. Eurobarometer, European Commission.

EDP Energía, 2016. Webpage of EDP Energía. EDP Energía, http://www.edpenergia.e (Retrieved 16-12-2016).

ENDESA, 2016. Webpage of ENDESA. ENDESA, https://www.endesa.com (Retrieved 16-12-2016). 
Capellán-Pérez, Iñigo; Álvaro Campos-Celador; and Jon Terés-Zubiaga. "Renewable Energy Cooperatives as an Instrument towards the Energy Transition in Spain.” Energy Policy 123 (December 1, 2018): 215-29. https://doi.org/10.1016/j.enpol.2018.08.064.

Engelken, M., Römer, B., Drescher, M., Welpe, I.M., Picot, A., 2016. Comparing drivers, barriers, and opportunities of business models for renewable energies: A review. Renew. Sustain. Energy Rev. 60, 795-809. https://doi.org/10.1016/j.rser.2015.12.163

Enzensberger, N., Fichtner, W., Rentz, O., 2003. Evolution of local citizen participation schemes in the German wind market. Int. J. Glob. Energy Issues 20, 191-207.

EOLPOP, 2017. Viure de l'aire. EOLPOP SL, http://www.viuredelaire.cat/en/what-iseolpop.html (Retrieved 14-12-2017).

Eurostat, 2018. Eurostat Database. European Commission, http://epp.eurostat.ec.europa.eu/portal/page/portal/eurostat/home/.

Évole, J., 2012. Oligopoly: el juego de la energía. Salvados.

EWS, 2016. Elektrizitätswerke Schönau - Who We Are. Elektrizitätswerke S c hön a u, https://www.ews-schoenau.de/ (Retrieved 10-10-2016).

FCECV, 2016. Federación Cooperativas Eléctricas de la Comunidad Valenciana webpage. Federación Cooperativas Eléctricas de la Comunidad Valenciana, http://www.coopelectricas.com (Retrieved 10-10-2016).

Fell, H.-J., 2017. The shift from feed-in-tariffs to tenders is hindering the transformation of the global energy supply to renewable energies.

Fleiß, E., Hatzl, S., Seebauer, S., Posch, A., 2017. Money, not morale: The impact of desires and beliefs on private investment in photovoltaic citizen participation initiatives. J. Clean. Prod. 141, 920-927.

Gallego-Castillo, C., Victoria, M., 2015. Cost-free feed-in tariffs for renewable energy deployment in Spain. Renew. Energy 81, 411-420. https://doi.org/10.1016/j.renene.2015.03.052

Gas Natural-Fenosa, 2016. Webpage of Gas Natural-Fenosa. Gas Natural-Fenosa, http://www.gasnaturalfenosa.es (Retrieved 16-12-2016).

Geels, F.W., 2014. Regime Resistance against Low-Carbon Transitions: Introducing Politics and Power into the Multi-Level Perspective. Theory Cult. Soc. 31, 21-40. https://doi.org/10.1177/0263276414531627

Geels, F.W., 2010. Ontologies, socio-technical transitions (to sustainability), and the multi-level perspective. Res. Policy, Special Section on Innovation and $\begin{array}{lll}\text { Sustainability } \quad \text { Transitions } & \text { 495-510. }\end{array}$ https://doi.org/10.1016/j.respol.2010.01.022

Geels, F.W., 2002. Technological transitions as evolutionary reconfiguration processes: a multi-level perspective and a case-study. Res. Policy, NELSON + WINTER + 20 31, 1257-1274. https://doi.org/10.1016/S0048-7333(02)00062-8

Geels, F.W., Kern, F., Fuchs, G., Hinderer, N., Kungl, G., Mylan, J., Neukirch, M., Wassermann, S., 2016. The enactment of socio-technical transition pathways: A reformulated typology and a comparative multi-level analysis of the German and UK low-carbon electricity transitions (1990-2014). Res. Policy 45, 896-913. https://doi.org/10.1016/j.respol.2016.01.015

Geels, F.W., Schot, J., 2007. Typology of sociotechnical transition pathways. Res. Policy 36, 399-417. https://doi.org/10.1016/j.respol.2007.01.003

GenerationkWh, 2017. GenerationkWh webpage. Som Energia, https://www.generationkwh.org (Retrieved 13-12-2017).

Gotchev, B., 2015. Market integration and the development of wind power cooperatives in Denmark, lessons learned for Germany. Inst. Adv. Sustain. Stud. Potsdam.

Haas, T., 2016. The Political Economy of Interrupted Energy Transitions: The Case of Spain. Work. Pap. 
Capellán-Pérez, Iñigo; Álvaro Campos-Celador; and Jon Terés-Zubiaga. "Renewable Energy Cooperatives as an Instrument towards the Energy Transition in Spain.” Energy Policy 123 (December 1, 2018): 215-29. https://doi.org/10.1016/j.enpol.2018.08.064.

Haas, T., 2014. Is Spain on the way to a new energy model?, in: Crisis, Resistance and Rights: Critical Political Economy Perspectives. Presented at the CPERN midterm conference, University of Vienna.

Hall, C.A.S., Klitgaard, K.A., 2012. Energy and the Wealth of Nations: Understanding the Biophysical Economy. Springer New York, New York, NY.

Hansen, J., Sato, M., 2016. Regional climate change and national responsibilities. Environ. Res. Lett. 11, 034009.

Hildmann, M., Ulbig, A., Andersson, G., 2013. Revisiting the merit-order effect of renewable energy sources. ArXiv Prepr. ArXiv13070444.

Horvat, B., 1982. The political economy of socialism: A Marxist social theory. Armonk, NY: ME Sharpe.

Huybrechts, B., 2013. Social Enterprise, Social Innovation and Alternative Economies: Insights from Fair Trade and Renewable Energy. Altern. Econ. Spaces New Perspect. Sustain. Econ. 113-130.

Huybrechts, B., Mertens, S., 2014. The Relevance of the Cooperative Model in the Field of Renewable Energy. Ann. Public Coop. Econ. 85, 193-212. https://doi.org/10.1111/apce.12038

Iberdrola, 2016. Webpage of Iberdrola Group. Iberdrola Group, https://www.iberdrola.com (Retrieved 16-12-2016).

IEA, 2016. Energy balances statistics. IEA/OCDE.

ILO, 2013. Providing clean energy and energy access through cooperatives. International Labour Office Cooperatives Unit (COOP) Green Jobs Programme, Geneva, Switzerland.

IPCC, 2014. Climate Change 2014: Mitigation of Climate Change. Fifth Assess. Rep. Intergov. Panel Clim. Change.

IRENA db, 2018. IRENA Resource (Database). International Renewable Energy Agency, http://resourceirena.irena.org.

Johanisova, N., Suriñach Padilla, R., Parry, P., 2014. Co-operatives. Degrowth Vocab. New Era.

Johanisova, N., Wolf, S., 2012. Economic democracy: A path for the future? Futures, Special Issue: Politics, Democracy and Degrowth 44, 562-570. https://doi.org/10.1016/j.futures.2012.03.017

Julian, C., 2014. Creating local energy economies: lessons from Germany. Respublica Lond.

Kampman, B., Blommerde, J., Afman, M., 2016. The potential of energy citizens in the European Union (No. 16.3J00.75). CE Delft.

Kunze, C., Becker, S., 2015. Collective ownership in renewable energy and opportunities for sustainable degrowth. Sustain. Sci. 1-13. https://doi.org/10.1007/s11625-0150301-0

Kunze, C., Becker, S., 2014. Energy democracy in Europe: A survey and outlook. Rosa Luxembg. Stift. Bruss. Off.

Laborde, D., 2011. Assessing the land use change consequences of European biofuel policies. Int. Food Policy Inst. IFPRI.

Lenton, T.M., Held, H., Kriegler, E., Hall, J.W., Lucht, W., Rahmstorf, S., Schellnhuber, H.J., 2008. Tipping elements in the Earth's climate system. Proc. Natl. Acad. Sci. 105, 1786-1793. https://doi.org/10.1073/pnas.0705414105

Madlener, R., 2007. Innovation diffusion, public policy, and local initiative: The case of wood-fuelled district heating systems in Austria. Energy Policy 35, 1992-2008. https://doi.org/10.1016/j.enpol.2006.06.010 
Capellán-Pérez, Iñigo; Álvaro Campos-Celador; and Jon Terés-Zubiaga. "Renewable Energy Cooperatives as an Instrument towards the Energy Transition in Spain.” Energy Policy 123 (December 1, 2018): 215-29. https://doi.org/10.1016/j.enpol.2018.08.064.

Mancinas-Chávez, R., Galán Linares, E., 2014. El programa “Salvados” en el sistema audiovisual español: elemento herético o la excepción que confirma la regla. "Salvados" within the context of the spanish audiovisual media system : heretical element or the exception that confirms the rule. https://doi.org/10.12795/anduli.2014.i13.07

Marco, A.M., 2012. Renovables, transparencia y mercado: el sistema de Garantía de Origen de la electricidad renovable en España. Universidad de Zaragoza.

Meadows, D.H., Randers, J., Meadows, D.L., 2004. The limits to growth: the 30-year update. Chelsea Green Publishing Company, White River Junction, Vt.

Motesharrei, S., Rivas, J., Kalnay, E., 2014. Human and nature dynamics (HANDY): Modeling inequality and use of resources in the collapse or sustainability of societies. Ecol. $\quad$ Econ. 101 90-102. https://doi.org/10.1016/j.ecolecon.2014.02.014

NRECA, 2016. The National Rural Electric Cooperative Association webpage. The National Rural Electric Cooperative Association, http://electric.coop (Retrieved 10-10-2016).

OCE, 2016. El carbón en España en 2016. El Observatorio Crítico de la Energía.

OCE, 2012. Entiende el mercado eléctrico. Observatorio Crítico de la Energía.

ODG, 2016. El Acaparamiento Energético del Estado español. Observatori del Deute en la Globalizació, Barcelona.

ODG, 2015. El coste real de la energía. Estudio de los pagos ilegítimos al sector eléctrico español 1998-2013. Observatori del Deute en la Globalizació, Barcelona, Spain.

Ortiz Castellví, L., 2013. Moción consecuencia de interpelación del Grupo Parlamentario de IU, ICV-EUiA, CHA: La Izquierda Plural, sobre política energética. Congreso de los Diputados, Madrid.

Px1NME, 2016. Plataforma por un Nuevo Modelo Energético webpage. Plataforma por un Nuevo Modelo Energético, http://www.nuevomodeloenergetico.org (Retrieved 10-10-2016).

Pye, S., Dobbins, A., 2015. Energy poverty and vulnerable consumers in the energy sector across the EU: analysis of policies and measures (Policy Report). Insight Energy.

Raskin, P.D., Electris, C., Rosen, R.A., 2010. The Century Ahead: Searching for Sustainability. Sustainability 2, 2626-2651. https://doi.org/10.3390/su2082626

REE, 2016a. Series Estadísticas del sistema eléctrico español. Red Eléctrica de España, http://www.ree.es/es/estadisticas-del-sistema-electrico-espanol/indicadoresnacionales/series-estadisticas.

REE, 2016b. Sistema Eléctrico Español 2015. Red Eléctrica de España.

REN21, 2016. Renewables 2016. Global Status Report. REN 21, Paris.

REScoop, 2016. REScoop.eu webpage. European Federation of Renewable Energy Cooperatives, https://rescoop.eu/ (Retrieved 10-10-2016).

Rijpens, J., Riutort, S., Huybrechts, B., 2013. Report on REScoop Business Models. REScoop. eu.

Riutort Isern, S., 2015. Reapropiación popular de la energía en los albores de una transición incierta Una contribución a partir del análisis de caso de Som Energia. Universidad de Barcelona (Spain).

Romero-Rubio, C., de Andrés Díaz, J.R., 2015. Sustainable energy communities: a study contrasting Spain and Germany. Energy Policy 85, 397-409. https://doi.org/10.1016/j.enpol.2015.06.012

Sáenz de Miera, G., del Río González, P., Vizcaíno, I., 2008. Analysing the impact of renewable electricity support schemes on power prices: The case of wind 
Capellán-Pérez, Iñigo; Álvaro Campos-Celador; and Jon Terés-Zubiaga. "Renewable Energy Cooperatives as an Instrument towards the Energy Transition in Spain.” Energy Policy 123 (December 1, 2018): 215-29. https://doi.org/10.1016/j.enpol.2018.08.064.

electricity in Spain. Energy Policy 36, 3345-3359. https://doi.org/10.1016/j.enpol.2008.04.022

Schneider, F., Kallis, G., Martínez-Alier, J., 2010. Crisis or opportunity? Economic degrowth for social equity and ecological sustainability. Introduction to this special issue. J. Clean. Prod. 18, 511-518. https://doi.org/10.1016/j.jclepro.2010.01.014

Schneider, M., Froggatt, A., Hazemann, J., 2012. The World Nuclear Industry Status Report 2012.

Schreuer, A., Weismeier-Sammer, D., 2010. Energy cooperatives and local ownership in the field of renewable energy technologies: A literature review (Research Reports No. RICC, 4). Vienna University of Economics and Business, vienna (Austria).

Smil, V., 2015. Power Density: A Key to Understanding Energy Sources and Uses. The MIT Press, Cambridge, Massachusetts.

Smil, V., 2008. Energy in nature and society: general energetics of complex systems. MIT Press, Cambridge, Massachusetts, USA.

Smith, A., Stirling, A., Berkhout, F., 2005. The governance of sustainable socio-technical transitions. $\quad$ Res. Policy 1491-1510. https://doi.org/10.1016/j.respol.2005.07.005

Som Energia, 2016. Som Energia webpage. Som Energia, https:/www.somenergia.coop/ (Retrieved 10-10-2016).

Steffen, W., Broadgate, W., Deutsch, L., Gaffney, O., Ludwig, C., 2015a. The trajectory of the Anthropocene: The Great Acceleration. Anthr. Rev. 2, 81-98. https://doi.org/10.1177/2053019614564785

Steffen, W., Richardson, K., Rockström, J., Cornell, S.E., Fetzer, I., Bennett, E.M., Biggs, R., Carpenter, S.R., Vries, W. de, Wit, C.A. de, Folke, C., Gerten, D., Heinke, J., Mace, G.M., Persson, L.M., Ramanathan, V., Reyers, B., Sörlin, S., 2015b. Planetary boundaries: Guiding human development on a changing planet. Science 347, 1259855. https://doi.org/10.1126/science.1259855

Tamames, R., 1967. Los monopolios en España. Zyx.

Tirado Herrero, S., Jiménez Meneses, L., López Fernández, J., Martín García, J., PereroVan-Hove, E., 2014. Pobreza energética en España. Análisis de tendencias. Asoc. Cienc. Ambient. ACA Madr.

Trainer, T., 2017. Some problems in storing renewable energy. Energy Policy 110, 386393. https://doi.org/10.1016/j.enpol.2017.07.061

Trainer, T., 2012. A critique of Jacobson and Delucchi's proposals for a world renewable energy supply. Energy Policy 44, 476-481. https://doi.org/10.1016/j.enpol.2011.09.037

Trainer, T., 2010. Can renewables etc. solve the greenhouse problem? The negative case. Energy Policy 38, 4107-4114. https://doi.org/10.1016/j.enpol.2010.03.037

UNCCUER, 2016. Web page of UNCCUER. Unión Renovables, Unión Nacional de Cooperativas de Consumidores y Usuarios de Energías Renovables, http://www.unionrenovables.coop/ (Retrieved 31-01-2017).

UNESA, 2015. Informe Eléctrico. Memoria de Actividades. Memoria Estadística 2014. Asociación Española de la Industria Eléctrica (UNESA).

UNESA, 2014. Contribución de las compañías que integran UNESA al desarrollo de la sociedad española. Asociación Española de la Industria Eléctrica, Madrid (Spain).

UNESA, 2013. La situación económico-financiera de la actividad eléctrica en España (1998-2012). UNESA, Madrid (Spain). 
Capellán-Pérez, Iñigo; Álvaro Campos-Celador; and Jon Terés-Zubiaga. "Renewable Energy Cooperatives as an Instrument towards the Energy Transition in Spain.” Energy Policy 123 (December 1, 2018): 215-29. https://doi.org/10.1016/j.enpol.2018.08.064.

Urkidi, L., Lago, R., Basurko, I., Mantxo, M., Barcena, I., Akizu, O., 2015. Transiciones energéticas: sostenibilidad y democracia energética. Universidad del País Vasco, Servicio Editorial= Euskal Herriko Unibertsitatea, Argitalpen Zerbitzua.

Valin, H., Peters, D., van den Berg, M., Frank, S., Havlik, P., Forsell, N., Hamelinck, C., Pirker, J., Mosnier, A., Balkovic, J., others, 2015. The land use change impact of biofuels consumed in the EU: Quantification of area and greenhouse gas impacts.

Vansintjan, D., 2015. The energy transition to energy democracy. Power to the people. Final results oriented report of the REScoop 20-20-20 Intelligent Energy Europe project. Antwerp. Disponible en: $<$ http://bit. ly/1LPkvZ5 $>$ [consulta: 29 de septiembre de 2015].

Viardot, E., 2013. The role of cooperatives in overcoming the barriers to adoption of renewable energy. Energy Policy 63, 756-764. https://doi.org/10.1016/j.enpol.2013.08.034

Viesgo, 2016. Webpage of Viesgo. Viesgo, http://viesgo.com (Retrieved 16-12-2016).

Wagner, O., Berlo, K., others, 2015. The wave of remunicipalisation of energy networks and supply in Germany: the establishment of 72 new municipal power utilities, in: EconStor Conference Papers. ZBW-German National Library of Economics.

Wang, J., Feng, L., Tang, X., Bentley, Y., Höök, M., 2017. The implications of fossil fuel supply constraints on climate change projections: A supply-side analysis. Futures 86, 58-72. https://doi.org/10.1016/j.futures.2016.04.007

Witkamp, M.J., Raven, R.P.J.M., Royakkers, L.M.M., 2011. Strategic niche management of social innovations: the case of social entrepreneurship. Technol. Anal. Strateg. Manag. 23, 667-681. https://doi.org/10.1080/09537325.2011.585035 